\title{
Growth, Feeding and Ecological Roles of the Mixotrophic and Heterotrophic Dinoflagellates in Marine Planktonic Food Webs
}

\author{
Hae Jin Jeong ${ }^{1 *}$, Yeong Du Yoo', Jae Seong Kim², Kyeong Ah Seong ${ }^{3}$, Nam Seon Kang', and Tae Hoon Kim ${ }^{4}$ \\ ${ }^{1}$ School of Earth and Environmental Sciences, College of Natural Sciences, Seoul National University, Seoul 151-747, Korea \\ ${ }^{2}$ Red Tide Research Center, Kunsan National University, Kunsan 573-701, Korea \\ ${ }^{3}$ Saemankeum Environmental Research Center, Kunsan National University, Kunsan 573-701, Korea \\ ${ }^{4}$ Research Institute of Oceanography, College of Natural Sciences, Seoul National University, Seoul 151-747, Korea
}

Received 15 March 2010; Revised 28 April 2010; Accepted 2 May 2010

(C) KSO, KORDI and Springer 2010

\begin{abstract}
$\overline{\text { Abstract - Planktonic mixotrophic and heterotrophic dinoflagellates }}$ are ubiquitous protists and often abundant in marine environments. Recently many phototrophic dinoflagellate species have been revealed to be mixotrophic organisms and also it is suggested that most dinoflagellates may be mixotrophic or heterotrophic protists. The mixotrophic and heterotrophic dinoflagellates are able to feed on diverse prey items including bacteria, picoeukaryotes, nanoflagellates, diatoms, other dinoflagellates, heterotrophic protists, and metazoans due to their diverse feeding mechanisms. In turn they are ingested by many kinds of predators. Thus, the roles of the dinoflagellates in marine planktonic food webs are very diverse. The present paper reviewed the kind of prey which mixotrophic and heterotrophic dinoflagellates are able to feed on, feeding mechanisms, growth and ingestion rates of dinoflagellates, grazing impact by dinoflagellate predators on natural prey populations, predators on dinoflagellates, and red tides dominated by dinoflagellates. Based on this information, we suggested a new marine planktonic food web focusing on mixotrophic and heterotrophic dinoflagellates and provided an insight on the roles of dinoflagellates in the food web.
\end{abstract}

Key words - grazing, harmful algal bloom, ingestion, predation, predator, prey, protist, red tide

Marine dinoflagellates are ubiquitous and some genera are cosmopolitan at present (Lessard 1984; Jeong 1999; Rublee et al. 2004). Also, they have been easily observed in the fossil record, reflecting their ubquitous presence in the past (e.g. Radi et al. 2007). They often dominate the plankton

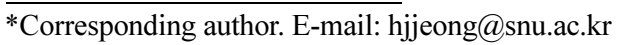

assemblages and sometimes form red tides or harmful blooms (e.g. Jeong 1999). They have very diverse morphology (size, shape etc.) and genetics which are two most critical keys for their classification (e.g. Daugbjerg et al. 2000). They have 3 different major trophic modes (i.e. autotrophic, mixotrophic, and heterotrophic) and the mixotrophic and heterotrophic dinoflagellates have diverse feeding mechanisms. Also, the mixotrophic and heterotrophic dinoflagellates are known to feed on diverse types and sizes of prey. In turn, dinoflagellates are excellent prey for mixotrophic and heterotrophic protists and mestazoans. Therefore, dinoflagellates play diverse roles in marine planktonic food webs.

In the last 2 decades, many phototrophic dinoflagellates which had previously been thought to be exclusively autotrophic dinoflagellates have been revealed to be mixotrophic dinoflagellates (i.e. capable of both photosynthesis and ingesting prey) (Jacobson and Anderson 1996; Stoecker 1999; Jeong et al. 2005c, 2010; Seong et al. 2006). The kind of prey which these mixotrophic dinoflagellates are able to feed on is very diverse including bacteria, other dinoflagellates, and heterotrophic protists. In particular, recently, feeding by dinoflagellates on a single bacterial cell has been confirmed (Seong et al. 2006; Jeong et al. 2008). Several dinoflagellate genera such as Karenia, Karlodinium, Lepidodinium have been discovered to have fucoxanthin or chlorophyll $b$ as accessary pigments, not peridinin which had been thought to be the common carotenoid accessary pigment of phototrophic dinoflagellates (Watanabe et al. 1990; Garces et al. 2006). Thus, it is believed that these 
pigments inside these dinoflagellates were originated from prey plastids through feeding (Bhattacharya et al. 2003). Feeding is likely to be one of the most important driving forces for the evolution of dinoflagellates. When combining the nutrition of modern dinoflagellates with the presence of fossil dinoflagellates in geological records, dinoflagellates have been ubiquitous for a long time (>100 MY) due to their diverse trophic modes and prey items. When their common prey became rare or disappeared in geological time scales, dinoflagellates might change their trophic modes and/or evolve their morphology and digestive enzymes to feed on the new prey items. Therefore, investigating predatorprey relationships among dinoflagellates and between dinoflagellates and diverse plankton and exploring roles of dinoflagellates in food webs may be critical steps in understanding the nature of the ecosystems at present and in the past and also evolution of dinoflagellates.

In this paper, we reviewed the kind of prey which mixotrophic and heterotrophic dinoflagellates are able to feed on, feeding mechanisms, growth and ingestion rates of dinoflagellates, grazing impact, and predators. In addition, we suggested a possible mechanism of the outbreak of red tides or harmful blooms dominated by mixotrophic dinoflagellates in offshore and/or oceanic waters where the nutrient concentrations are low. We also suggested new marine planktonic food webs focussing on dinoflagellates based on the literature and also addressed the roles of dinoflagellates in these food webs. In the section on the kind of prey and feeding mechanisms, i) whether dinoflagellates are able to feed on most types and sizes of prey, even very small or large prey, ii) if so, how dinoflagellates capture and ingest these diverse prey, and iii) in an evolutionary sense, whether morphological diversity of dinoflagellates could be related to their feeding mechanisms were explored. In the section on the growth and ingestion rates and grazing impact by dinoflagellates on diverse prey, iv) when these predators' sizes are similar, whether the maximum growth rates of autotrophic, mixotrophic, and heterotrophic dinoflagellates are also similar or not, v) whether the maximum ingestion rates of mixotrophic dinoflagellates are comparable to those of heterotrophic dinoflagellates or not, and vi) what are the important factors affecting the maximum growth and ingestion rates were investigated. In the section on predators, vii) whether maximum ingestion rates of major predators (other dinoflagellates, ciliates, and copepods) on mixotrophic dinoflagellates are similar to those of heterotrophic dinoflagellates and viii) whether the mortality rate of dinoflagellate prey due to predation by heterotrophic protistan and metazoan predators is critical in controlling dinoflagellate red tides were addressed.

This review paper provides an insight on how dinoflagellates come to be ubiquitous and often dominate the plankton assemblages at present and in the past, how dinoflagellates have diverse trophic modes, feeding mechanisms, and diverse prey items, and to which direction dinoflagellates have evolved their morphology and/or enzymes.

\section{Trophic Modes}

Marine dinoflagellates have 3 major trophic modes (i.e. autotrophy, mixotrophy, and heterotrophy) (Lessard and Swift 1985; Burkholder et al. 1992; Steidinger et al. 1996; Sherr and Sherr 2002; Mason et al. 2007). Phototrophic dinoflagellates (autotrophic or mixotrophic dinoflagellates) have been thought to be one of the most important phytoplankton groups for a long time. Therefore, there have been many studies on the ecology and physiology of the phototrophic dinoflagellates assuming that they were exclusively autotrophic dinoflagellates (e.g. Smayda 1997). They have often formed huge red tides which have sometimes caused large-scale mortalities of fin-fish and shellfish and thus great losses to the aquaculture and tourist industries of many countries (ECOHAB 1995; Azanza et al. 2005). The mechanisms of the outbreak, persistence, and decline of the red tides dominated by phototrophic dinoflagellates have also been studied based on the assumption that they were exclusively autotrophic dinoflagellates. However, many phototrophic dinoflagellates have recently been revealed to be mixotrophic dinoflagellates (MTDs) and thus the study on phagotrophy of phototrophic dinoflagellates is rapidly increasing (Larsen 1988; Jacobson and Anderson 1994; Granéli et al. 1997; Jeong et al. 1997; Adolf et al. 2006; Burkholder et al. 2008). In addition, recently some newly described phototrophic dinoflagellate species have been revealed to be mixotrophic dinoflagellates (e.g. Kang et al. 2010; Yoo et al. 2010). Thus, mixotrophy by the causative phototrophic dinoflagellate species should be considered when the mechanisms of the outbreak, persistence, and decline of red tides are being explored.

Heterotrophic dinoflagellates (HTDs) have been known to have diverse feeding mechanisms and feed on diverse prey (e.g. Hansen and Calado 1999). Recently, their feeding 
mechanisms and prey items have been newly discovered (e.g. Jeong et al. 2008). Thus, difference in maximum growth rates among similar-sized autotrophic, mixotrophic, and heterotrophic dinoflagellates and differences in the kind of prey, feeding mechanisms, and maximum ingestion rates between MTDs and HTDs may give a clue to understanding the evolution in the trophic modes of dinoflagellates in a geological time scale.

\section{The Kind of Prey which Dinoflagellates are Able to Feed on}

Mixotrophic and heterotrophic dinoflagellates usually co-occur with diverse types and sizes of plankton in marine environments. Thus, the following questions arise; (1) Are dinoflagellats able to feed on most plankton taxa? Even toxic prey species? (2) Is the kind of prey which MTDs are able to feed on different from that of HTDs? (3) Are dinoflagellats able to feed on plankton prey with a wide range of size, even very small (i.e. bacteria) or large prey (larval fish)? If so, how do dinoflagellates capture and ingest these very small or large prey? (i.e. what are their feeding mechanisms?) (4) Is the lower or upper prey size limit affected by the predator size?

\section{2a. Prey taxa}

Both MTDs and HTDs have been known to feed on diverse taxa including phototrophic (Strom 1991; Jeong et al. 2005b) and heterotrophic bacteria (Jeong et al. 2008), pico-eukaryotes (Lee 2006), cryptophytes ( $\mathrm{Li}$ et al. 2000), haptophytes (Goldman et al. 1989; Berge et al. 2008), chlorophytes (Strom and Buskey 1993), prasiophytes (Berge et al. 2008), raphidophytes (Nakamura et al. 1995), diatoms (Jacobson and Anderson 1986; Menden-Deuer et al. 2005; Yoo et al. 2009), other dinoflagellates (Adolf et al. 2007; Tillmann 2004), heterotrophic nanoflagellates (Jeong et al. 2007b), and ciliates (Hansen 1991; Bockstahler and Coats 1993a, 1993b) (Table 1). However, some HTDs have been reported to be able to feed on the blood, flesh, eggs, early naupliar stages, and adult forms of metazoans, while MTDs

Table 1. The kind of prey taxa which mixotrophic (MTD) and heterotrophic dinoflagellate (HTD) are able to feed on. (DE: Direct engulfment feeders, PAL: Pallium feeders, PED: Peduncle feeders, Numbers: feeding occurred and numbers are references, -: tested, but not found yet, Blank: not tested)

\begin{tabular}{|c|c|c|c|c|c|}
\hline$\overline{\overline{P r e y} / \text { Predator }}$ & "MTD & 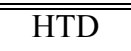 & $\overline{\mathrm{DE}}$ & PAL & 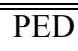 \\
\hline heterotrophic bacteria & (1) & $(2,3)$ & (3) & (3) & (4) \\
\hline autotrophic bacteria & $(5)$ & (6) & $(6)$ & & (4) \\
\hline pico-eukaryotes & (7) & & & & \\
\hline Cryptophytes & (8) & $(9,10)$ & (11) & $(10)$ & (4) \\
\hline Haptophyta (=Prymnesiophyta) & (12) & $(13,10)$ & (13) & $(10)$ & $(12)$ \\
\hline Chlorophytes (Dunaliella) & & $(13,10)$ & (13) & $(10)$ & \\
\hline Prasionphytes & (12) & $(10)$ & (14) & $(15)$ & \\
\hline \multicolumn{6}{|l|}{ Euglenophytes } \\
\hline Raphidophytes & (12) & $(15,16)$ & $(15)$ & $(16)$ & $(16)$ \\
\hline Bacillariophytes & (17) & $(18,19)$ & $(18)$ & $(20)$ & (19) \\
\hline Dinoflagellates & $(21)$ & $(22,16)$ & $(22)$ & (13) & $(16)$ \\
\hline Heterotrophic nanoflagellates & $(23)$ & $(24)$ & $(24)$ & & $(24)$ \\
\hline Ciliates & $(25,26)$ & (4) & $(27)$ & & $(26)$ \\
\hline Eggs of metazoans & - & $(28,29)$ & & $(28)$ & $(29)$ \\
\hline Naupliar stages of metazoans & - & $(28,29)$ & & $(21)$ & $(29)$ \\
\hline Bloods of metazoans & - & $(29)$ & & & $(29)$ \\
\hline Flesh of metazoans & - & (29) & & & $(29)$ \\
\hline
\end{tabular}

Note. (1): Seong et al. (2006), Nygaard and Tobiesen (1993), (2): Lessard and Swift (1985), Burkholder and Glasgow (1995, 1997), (3): Jeong et al. (2008), (4): Burkholder and Glasgow (1995), (5): Jeong et al. (2005b), (6): Strom (1991), Glasgow et al. (1998); (7): Lee (2006), (8): Li et al. (2000), Jakobsen et al. (2000), Stoecker et al. (1997), (9): Feinstein et al. (2002), (10): Strom and Buskey (1993), (11): Jakobson and Hansen (1997), (12): Berge et al. (2008), (13): Goldman et al. (1989), (14): Hansen et al. (1996), (15): Nakamura et al. (1992), (16): Jeong et al. (2006, 2007a), (17): Legrand et al. (1998), Bockstahler and Coats (1993b), (18): Naustvoll LJ (1998), Nakamura et al. (1995), Hansen PJ (1992), Strom and Buskey (1993), (19): Parrow et al. (2001), (20): Menden-Deuer et al. (2005), (21): Skovgaard (1996a), Hansen and Nielsen (1997), (22): Nakamura et al (1995), (23): Jeong et al. (unpubl.data), (24): Jeong et al. (2007b), (25): Smalley et al. (1999), Bockstahler and Coats (1993a), Hansen PJ (1991), (26): Park et al. (2006), (27): Bursa AS (1961), (28): Jeong (1994b), (29): Burkholder and Glasgow (1997) 

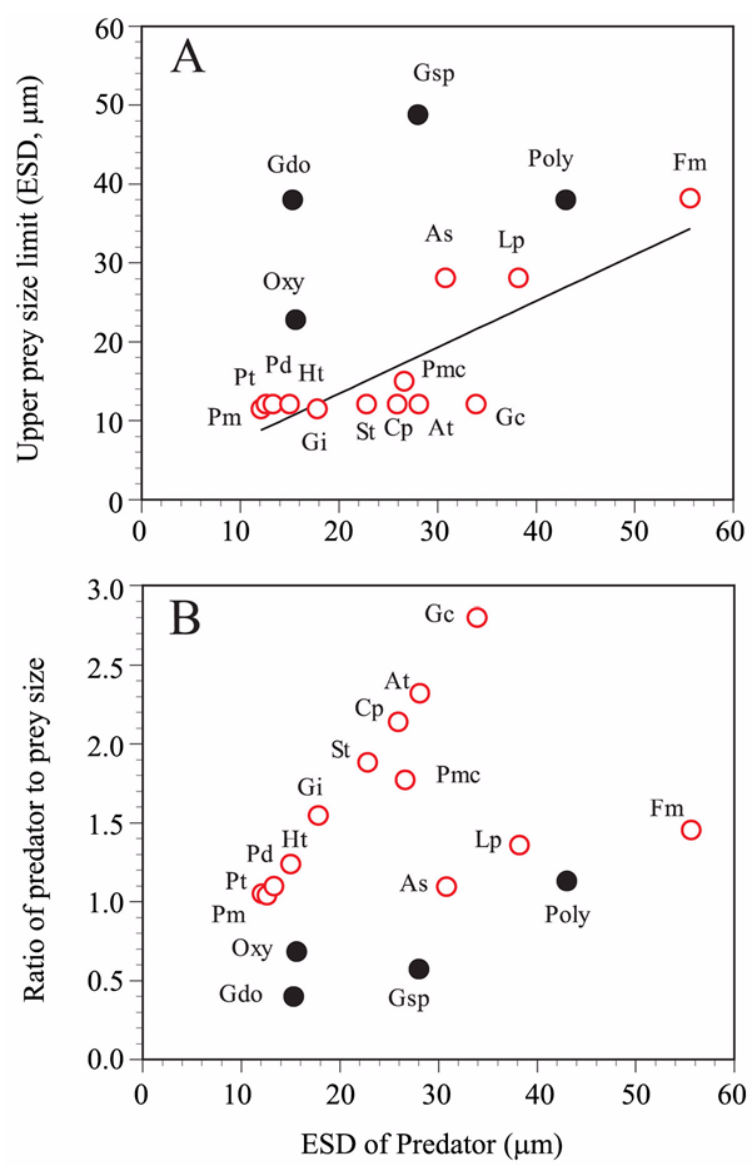

Fig. 1. The size (Equivalent Spherical Diameters, ESD, $\mu \mathrm{m}$ ) of the largest prey which engulfment feeding mixotrophic (A. open circles, MTD) and heterotrophic dinoflagellates (B. closed circles, HTD) are able to feed on as a function of the predator size. The equation of the regression was ESD of the MTD predator $(\mu \mathrm{m})=0.587$ (ESD of prey) + $1.67, \mathrm{r}^{2}=0.687(\mathrm{p}<0.005)$

(At: Alexandrium tamarense, As: Akashiwo sanguinea, $\mathrm{Cp}$ : Cochlodinium polykrikoides, Fm: Fragilidium cf. mexicanum, Gc: Gymnodinium catenatum, Gi: Gymnodinium impudicum, Ht: Heterocapsa triquetra, Lp: Lingulodinium polyedrum, Pd: Prorocentrum donghaiense, Pmc: P. micans, Pm: P. minimum, Pt: P. triestinum, St: Scrippsiella trochoidea, Oxy: Oxyrrhis marina, Gdo: Gyrodinium dominans, Gsp: Gyrodinium spirale, Poly: Polykrikos kofoidii)

were not (e.g. Jeong 1994b, 2007a). Among HTDs, the pallium (feeding veil) and peduncle (feeding tube) feeders were known to be able to feed on these animal prey items, while the engulfment feeders were not (see feeding mechanism section for details). For the engulfment feeding HTDs, eggs, early naupliar stages, and adult forms of metazoans are too large to engulf. There are some MTD species that feed on prey using a peduncle (Park et al. 2006; Berge et al. 2008; Jeong et al. 2010; Yoo et al. 2010). Therefore, it is worthwhile to discover any MTD that is able to feed on these animal prey items.

Even though several MTDs and HTDs have co-occurred with euglenophytes during euglenophyte blooms (our unpublished data), there has been no study on feeding by MTDs and HTDs on euglenophytes yet. It is worthwhile to explore this topic to understand the dynamics of euglenophytes and roles of dinoflagellates in these dynamics. Also, there has been no study on the feeding by MTDs on chlorophytes yet. Further study on whether MTDs and HTDs are able to feed on prey not tested yet is necessary (Table 1).

\section{2b. Toxic prey}

Some MTDs and HTDs were able to feed on toxic algae; the MTDs Lingulodinium polyedrum and Akashiwo sanguinea were able to feed on the toxic dinoflagellate Alexandrium tamarense (Jeong et al. 2005c); also, the HTDs Polykrikos kofoidii fed on the toxic MTD Gymnodinium catenatum and detoxified the toxin produced by the prey (Jeong et al. 2003b). These dinoflagellates may have enzyme-detoxifying phytotoxins and it is worthwhile to explore the presence and nature of these enzymes. Dinoflagellates may evolve to feed on toxic algae which might evolve to have toxins for anti-predation.

\section{2c. Size of prey and predator}

The size range of plankton co-occurring with dinoflagellates are very wide, from very small bacteria to large larval fish. Many think that a single bacterium cell is too small to be eaten by dinoflagellates. Some studies reported signs of bacteria inside some MTD and HTD predators using bacteria prelabelled with tritiated-thymidine (Lessard and Swift 1985; Nygaard and Tobiesen 1993). However, these studies neither reported the feeding behavior of HTDs on bacteria nor provided transmission electron microscopy (TEM) pictures showing ingested bacterial cells or bacteria sized beads in the food vacuoles inside the protoplasm of predator cells. Therefore, for a long time, some argued that the signs of bacteria inside the dinoflagellate predators might be derived from detritus to which the bacteria are attached or labelled bacteria sticked to the predator surface. Recently, Seong et al. (2006) and Jeong et al. (2005b, 2008), using confocal microscopy, TEM, and video microscopy (see details in the feeding mechanism section), have clearly showed that MTDs and HTDs were able to feed on a single bacterium cell. Therefore, the lower prey size limits of MTDs and HTDs goes down to pico-size. In many previous studies, the lower prey size limits of MTDs and HTDs had 
Table 2. Feeding occurrence by each mixotrophic dinoflagellate predator on diverse prey items which were identified in the taxonomic level listed below

$((+)$ : A dinoflagellate predator was observed to feed on prey cells, (--): the dinoflagellate predator was observed not to feed on prey cells, No (+) or (--) means not tested, ESD: Equivalent Spherical Diameters $(\mu \mathrm{m})$, HB: Heterotrophic bacteria, CB: Cyanobacteria, HP: Haptophyte, CR: Cryptophyte, Ac: Amphidinium carterae, DA: a small diatom, Ha: Heterosigma akashiwo, Pm: Prorocentrum minimum, Ht: Heterocapsa triquetra, Cp: Cochlodinium polykrikoides, Pc: P. micans, At: Alexandrium tamarense, As: Akashiwo sanguinea, Lp: Lingulodinium polyedrum, Ce: Ceratium spp., HD: Heterotrophic dinoflagellates, CL: Ciliates)

\begin{tabular}{|c|c|c|c|c|c|c|c|c|c|c|c|c|c|c|c|c|c|c|c|}
\hline Predator / Prey & ESD & $\overline{\mathrm{HB}}$ & 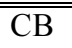 & 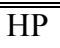 & 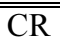 & Ac & 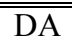 & $\overline{\mathrm{Ha}}$ & $\mathrm{Pm}$ & $\overline{\mathrm{Ht}}$ & $\mathrm{Cp}$ & Pc & At & As & Lp & $\mathrm{Ce}$ & $\begin{array}{l}\mathrm{HD} \\
\end{array}$ & $\overline{\mathrm{CL}}$ & Ref. \\
\hline Heterocapsa rotundata & 5.8 & + & + & & & & + & & & & & & & & & & & & $(6,11,15)$ \\
\hline Imphidinium carterae & 6.6 & & & & & & + & & & & & & & & & & & & (15) \\
\hline Prorocentrum minimum & 12.1 & + & + & + & + & + & + & + & & -- & -- & -- & -- & -- & -- & & & & $(6,7,9,11,13$, \\
\hline Paragymnodinium shiwhaense & 12.4 & & & + & + & + & -- & + & -- & -- & -- & -- & -- & -- & -- & & & & (18) \\
\hline Gyrodinium galatheanum & 12.5 & & & & + & & & & & & & & & & & & & & (9) \\
\hline Prorocentrum triestinum & 12.6 & + & & + & + & + & + & + & + & -- & -- & -- & -- & -- & -- & & & & $(6,7,11,15)$ \\
\hline Karlodinium armiger & 13.1 & & & + & + & & + & + & + & + & & + & & + & & & + & & (17) \\
\hline Prorocentrum donghaiense & 13.3 & + & + & + & + & + & + & + & + & -- & -- & -- & -- & -- & -- & & & & $(6,7,11,15$ \\
\hline Heterocapsa triquetra & 15.0 & + & + & + & + & + & + & + & + & & -- & -- & -- & -- & -- & & & & $(6,7,11,15)$ \\
\hline 1 lexandrium minutum & 16.7 & & + & & & & & & & & & & & & & & & & (6) \\
\hline Gymnodinium $i$ & 17.8 & + & + & + & + & + & + & + & -- & -- & -- & -- & -- & -- & -- & & & & $(6,7,11,15)$ \\
\hline Gymnodinium a & 19.4 & + & + & + & + & + & -- & + & -- & -- & -- & -- & -- & -- & -- & & & & (16) \\
\hline Karenia brevis & 20.3 & & + & & & & & & & & & & & & & & & & (6) \\
\hline Scrippsiella trochoidea & 22.8 & & + & + & + & + & + & + & + & -- & -- & -- & -- & -- & -- & & & & $(6,7,11,15$ \\
\hline Cochlodinium polykrikoides & 25.9 & + & + & + & + & + & + & + & -- & -- & & -- & -- & -- & -- & & & & $(6,7,11,15)$ \\
\hline Prorocentrum $n$ & 26.6 & + & + & + & + & + & + & + & + & + & -- & & -- & -- & -- & & & & $(6,7,11,15)$ \\
\hline Alexandrium tamarense & 28.1 & + & + & + & + & + & + & + & + & -- & -- & -- & & -- & -- & & & & $(6,7,11,15)$ \\
\hline Ceratium furca & 29.0 & & & & & & & & & & & & & & & & & + & (3) \\
\hline Gyrodinium pavillardi & 29.5 & & & & & & & & & & & & & & & & & + & (1) \\
\hline Akashiwo sanguinea & 30.8 & + & + & + & + & + & + & + & + & + & -- & -- & + & & -- & & & + & $(2,3,6,7,11,1$ \\
\hline Gonyaulax polygramma & 32.5 & + & + & + & + & + & + & + & + & + & -- & -- & -- & -- & -- & & & & $(6,8,11,15)$ \\
\hline Alexandrium catenella & 32.6 & + & + & & & & & & & & & & & & & & & & $(6,11)$ \\
\hline Gymnodinium catenatum & 33.9 & + & + & + & + & + & + & + & + & -- & -- & -- & -- & -- & -- & & & & $(6,7,11,15)$ \\
\hline Gonyaulax spinifera & 35.0 & & + & & & & & & & & & & & & & & & & (6) \\
\hline Lingulodinium polyedrum & 38.2 & + & + & + & + & + & + & + & + & + & 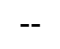 & -- & + & -- & & & & & $(6,7,11,15)$ \\
\hline Gyrodinium uncatenum & 39.0 & & & & & & & & & & & & & & & & & + & (3) \\
\hline Gyrodinium instriatum & 43.2 & & & & & & & & & & & & & & & & & + & (14) \\
\hline Fragilidium subglobosum & 50.0 & & & & & & & & & & & & & & & + & & & (12) \\
\hline Fragilidium mexicanum & 55.6 & & & & & -- & & & + & & -- & + & & + & + & & + & & (4) \\
\hline
\end{tabular}

Note. (1): Biecheler (1952), (2): Bockstahler and Coats (1993a), (3): Bockstahler and Coats (1993b), (4): Jeong et al. (1999a), (5): Jeong et al. (2004c), (6): Jeong et al. (2005b), (7): Jeong et al. (2005c), (8): Jeong et al. (2005d), (9): Li et al. (1996), (10): Nygaard and Tobiesen (1993), (11): Seong et al. (2006), (12): Skovggard (1996a), (13): Stoecker et al. (1997), (14): Uchida et al. (1997), (15): Yoo et al. (2009), (16): Jeong et al. (2010), (17): Berge et al. (2008), (18): Yoo et al. (2010)

been reported to be 3-4 $\mu \mathrm{m}$ (Hansen 1992; Jakobsen and Hansen 1997; Hansen and Calado 1999). These studies tested algal prey with the assumption that dinoflagellates might feed on prey using raptorial feeding (see feeding mechanism section). However, some small HTDs fed on a single bacterum cell using feeding mechanisms (filter/ interception feeding) different from those used for large algal prey (Jeong et al. 2008). Discovery of new feeding mechanisms of dinoflagellates might give a clue for understanding feeding by dinoflagellates on a single bacterium cell.

For the engulfment feeding dinoflagellates, the size (Equivalent Spherical Diameter, ESD) of the largest prey which MTDs are able to feed on was significantly positively correlated with the ESD's of the predators ( $p<0.005$, linear regression ANOVA; Fig. 1A). These MTDs engulf large prey cells through the sulcus which is in general proportional to the body size (Jeong et al. 2005c). Thus, in general the upper size limit of prey for the engulfment feeding MTDs is 
proportional to the predator size (Table 2). However, the ESD of the largest prey which the engulfment feeding HTDs are able to feed on was not significantly positively correlated with the ESD's of the predators ( $p>0.1$; Fig. 1B). When the sizes are similar, the upper prey size limits of the HTDs were larger than those of MTDs and thus the ratios of predator to prey size for the HTDs were clearly lower than those of the MTDs (Fig. 1A and B). These HTDs may have more flexible sulcus than the MTDs. Also, microtubles involved in opening and closing sulcus of HTDs may be more well developed than MTDs. In addition, force involved in pulling prey cells into the protoplasm of HTDs may be stronger than those of MTDs. Further study on this topic is necessary.

The pallium feeding HTDs or peduncle feeding MTDs and HTDs are able to feed on prey larger than themselves (Gaines and Taylor 1984; Jacobson 1987; Jeong et al. 2007a; Berge et al. 2008; Yoo et al. 2010) (see next subsection for details). Therefore, their upper prey size limits are larger than those of the engulfment feeding MTDs and HTDs.

\section{Feeding Mechanisms and Evolution in Morphology}

Dinoflagellates are able to feed on diverse types and sizes of prey as mentioned above. Thus, several questions arise; (1) what are feeding mechanisms of dinoflagellates? Are they diverse? (2) Is there any dinoflagellate having 2 or more feeding mechanisms? (3) What makes feeding mechanisms of dinoflagellates be diverse? (4) Is there any relationship between the morphology and feeding mechanisms of dinoflagellates?

\section{3a. Types}

In general, there are 3 major feeding mechanisms of freeliving protists (Boenigk and Arndt 2000; Fenchel 1987; Sleigh 1989): raptorial feeding, filter/interception feeding, and diffusion feeding. In raptorial feeding, predators search, capture, ingest, and digest prey cells, while in filter/ interception feeding, predators generate feeding currents and filter or intercept prey cells in the feeding current. In diffusion feeding, predators wait until prey cells arrive in the feeding part of the predators and ingest the prey cells. For a long time, many studies reported that planktonic dinoflagellates fed on prey cells using raptorial feeding because these studies focused on nano-sized or larger prey.
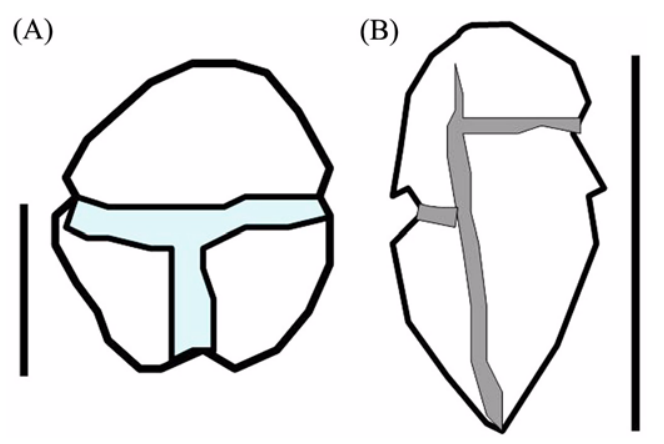

Fig. 2. A diagram of possible evolution in the morphology of dinoflagellates ingesting a prey cell through the sulcus. Dinoflagellates with a large displacement of the cingulum and/or extension of the sulcus (Dinoflagellate B) may have an advantage in engulfing larger prey cells over ones with smaller or no displacement of the cingulum (Dinoflagellate A)

\section{3b. The number and size of the mouth}

There are 3 major feeding mechanisms in the raptorial feeding; direct engulfment feeding, pallium feeding, and peduncle feeding. Direct engulfment feeders ingest prey cells through openings (like mouth) of the predator body. Thus, several questions arise; (1) where is a mouth? (2) Is there only one mouth in a dinoflagellate? (3) Is it located in a similar area among dinoflagellates? Most dinoflagellates are known to engulf a prey cell through the sulcus (Skovgaard 1996a; Jeong et al. 2005c). However, recently it was found that the MTDs Gonyaulax polygramma and Scrippsiella spp. engulfed a small prey through the apical horn, whereas they engulfed a larger prey through the sulcus (i.e. 2 mouths; Jeong et al. 2005c, 2005d). Surprisingly, Prorocentrum spp. engulfs prey cells through sutures on the sides of several parts of their bodies (i.e. multiple mouths; Jeong et al. 2005c). Sometime a P. micans cell engulfed 3 cyryptophyte prey cells at 3 different locations simultaneously. Therefore, the sulcus, apical horn, and suture are mouths of dinoflagellates and some dinoflagellates have 2 or more mouths. Considering the locations through which the dinoflagellates engulf, the dinoflagellates are close to amoebae that engulf prey cells through several parts of the body rather than common ciliates that engulf prey cells through the cytostome.

The size of the opening (sulcus, apical horn, suture etc.) is likely to be one of the critical factors determining predator and prey in the feeding battle among the engulfment feeding dinoflagellates (Jeong et al. 2005c). For dinoflagellates ingesting a prey cell through the sulcus, having a large displacement of the cingulum and/or extension of the sulcus may provide 
an advantage in engulfing larger prey cells over dinoflagellates with smaller or no displacement of the cingulum (Fig. 2). The engulfment feeding dinoflagellates may evolve to have larger openings to engulf larger prey cells.

Dinoflagellates may develop pallium or peduncle feeding mechanisms to feed on prey larger than the predator themselves, as mentioned above. Some pallium and peduncle feeding dinoflagellates are able to feed on prey 10 times larger than themselves (e.g. Jacobson 1987). Unlike most engulfment feeding dinoflagellates, several pallium and peduncle feeding dinoflagellate cells are able to attack a prey cell simultaneously (Jeong 1994b). When the range of size and types of prey are considered, the pallium or peduncle feeding dinoflagellates may be more evolved than the direct engulfment feeding dinoflagellates.

\section{3c. Feeding mechanism for bacterial prey}

Is a dinoflagellate able to feed on bacterium cells using raptorial feeding? Dinoflagellates may have difficulty in detecting and capturing tiny bacterium cells. Jeong et al. (2008) revealed that the HTDs Oxyrrhis marina and Gyrodinium spp. fed on a single bacterium cell like filter/ interception feeders; they generate feeding currents using the flagella. In O. marina feeding, feeding currents moved from above the predator toward the cingular depression of the predator along the flow lines (Fig. 3A). O. marina intercepted and then ingested a single bacterial cell in the feeding current. In Gyrodinium spp. feeding, feeding currents flowed from above the epicone of the predator, via the long and narrow sulcus, to below the hypocone of the predator or flowing along the sides of the body of the predator, via the cingulum and the sulcus, to below the hypocone. Gyrodinium spp. ingested a single living bacterium in the feeding currents when the prey arrived at the lower part of the sulcus, by interception. Displacement in the cingulum of dinoflagellates (like Gyrodinium spp.) makes a longer and narrower sulcus that in turn may generate a stronger feeding current due to venturi effect (Fig. 3B). Also, bacterial cells in the narrower sulcus may be more easily captured by the predator than those in the wider sulcus. The peduncle cover of Pfiesteria piscicida is likely to make a narrow duct and thus may also generate a strong feeding current to feed on pico-sized prey (Fig. 3C). Thus, morphological characteristics of HTDs such as cingular depression, long and narrow sulcus, and probably peduncle cover may be a result of evolution to feed on pico-sized prey. It
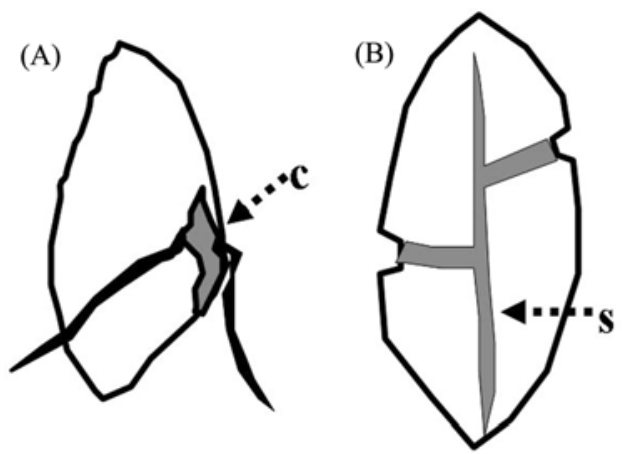

(C)

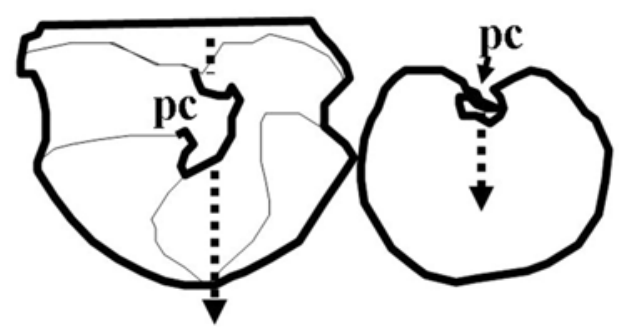

Fig. 3. Some morphological characteristics of heterotrophic dinoflagellates such as cingular depression (A. Oxyrrhis marina), long and narrow sulcus (B. Gyrodinium sp.), and probably the peduncle cover of Pfiesteria piscicida (C) may be a result of evolution to feed on pico-sized prey. Displacement in the cingulum of dinoflagellates (B) makes a longer and narrower sulcus which in turn may generate a stronger feeding current due to venturi effect. c: cingular depression, s: sulcus, pc: peduncle cover

is worthwhile to explore relationships among the morphology, feeding mechanisms, and evolution of dinoflagellates.

\section{3d. Number of feeding mechanisms for a dinoflagellate predator}

Oxyrrhis marina and Gyrodinum spp. exhibit 2 different feeding behaviors; they feed on pico-sized prey as described above and they engulf nano- or micro-sized prey through the cingulum depression and the sulcus. The MTD Karlodinium armiger also exhibit 2 different feeding mechanisms (Berge et al. 2008): it fed on small prey cells using direct engulfment, while it fed on large prey using peduncle feeding. Some dinoflagellates may have evolved to feed on more diverse prey items by utilizing different feeding behaviors depending on the type and/or size of prey. These dinoflagellates have an advantage in gaining energy compared to predators that have only one feeding behavior that limits them to being able to feed on only a certain sized prey.

Which feeding mechanism of dinoflagellates is better? The MTD Fragilidium cf. mexicanum can feed on the HTD 
Table 3. Maximum growth rate of each mixotrophic dinoflagellate species when growing photosynthetically (ESD: Equivalent spherical diameter $(\mu \mathrm{m}), \mathrm{T}$ : Temperature $\left({ }^{\circ} \mathrm{C}\right), \mathrm{MGR}$ : Maximum growth rate $\left.\left(\mathrm{d}^{-1}\right)\right)$

\begin{tabular}{|c|c|c|c|c|}
\hline Species name & "ESD & 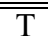 & MGR & Ref. \\
\hline Prorocentrum minimum & 12.1 & 25 & 0.942 & Kondo et al. (1990) \\
\hline Prorocentrum donghaiense & 13.2 & 20 & 0.821 & Jeong et al. (unpubl data) \\
\hline Heterocapsa triquetra & 15.1 & 15 & 0.720 & Hansen (2002) \\
\hline Heterocapsa circularisquama & 18.0 & 30 & 0.901 & Yamaguchi et al. (1997) \\
\hline Gymnodinium aureolum & 19.4 & 20 & 0.120 & Jeong et al. (2010) \\
\hline Gymnodinium impudicum & 22.0 & 30 & 0.580 & Jeong et al.(unpubl data) \\
\hline Karenia brevis & 23.0 & 20 & 0.400 & Richardson et al. (2006) \\
\hline Ceratium lineatum & 25.0 & 15 & 0.220 & Hansen et al. (2007) \\
\hline Cochlodinium polykrikoides & 25.8 & 25 & 0.576 & Jeong et al. (unpubl data) \\
\hline Prorocentrum micans & 26.6 & 20 & 0.531 & Jeong et al. (unpubl data) \\
\hline Ceratium furca & 28.1 & 24 & 0.720 & Baek et al. (2008) \\
\hline Alexandrium affine & 29.7 & 25 & 0.598 & Jeong et al.(unpubl data) \\
\hline Alexandrium tamarense & 29.7 & 15 & 0.381 & Yamamoto \& Tarutani (1997) \\
\hline Akashiwo sanguinea & 30.8 & 25 & 0.783 & Matsubara et al. (2007) \\
\hline Gonyaulax polygramma & 32.5 & 20 & 0.488 & Jeong et al.(unpubl data) \\
\hline Gymnodinium catenatum & 33.9 & 25 & 0.407 & Jeong et al. (unpubl data) \\
\hline Alexandrium catenella & 34.0 & 14 & 0.208 & Navarro et al. (2006) \\
\hline Gyrodinium instriatum & 36.5 & 20 & 0.510 & Nagasoe et al. (2006) \\
\hline Lingulodinium polyedrum & 36.6 & 20 & 0.182 & Jeong et al. (2005c) \\
\hline Fragilidium subglobosum & 45.0 & 15 & 0.160 & Hansen and Nielsen (1997) \\
\hline
\end{tabular}

Table 4. Optimal prey and maximum mixotrophic growth (MGR), ingestion (MIR), and clearance rates (MCR) of each mixotrophic dinoflagellate predator species

(ESD: Equivalent spherical diameter $(\mu \mathrm{m})$, RPP: ratio of predator to prey ESD, T: Temperature $\left({ }^{\circ} \mathrm{C}\right)$, LI: Light intensity $\left(\mu \mathrm{E} \mathrm{m}^{-2} \mathrm{~s}^{-1}\right)$, MGR: Maximum growth rate $\left(\mathrm{d}^{-1}\right)$, MIR: Maximum ingestion rate $\left(\right.$ ng $\mathrm{C}$ grazer $\left.{ }^{-1} \mathrm{~d}^{-1}\right)$, MCR: Maximum clearance rate $(\mu \mathrm{l}$ $\left.\left.\operatorname{grazer}^{-1} h^{-1}\right)\right)$

\begin{tabular}{|c|c|c|c|c|c|c|c|c|c|c|}
\hline Predator & 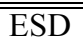 & Optimal prey & 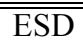 & RPP & $\overline{\mathrm{T}}$ & 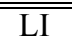 & MGR & MIR & "MCR & Ref. \\
\hline Gymnodinium gracilentum* & 9.1 & Teleaulax amphioxeia & 8.5 & 1.1 & 15 & 60 & 1.510 & 0.08 & & (1) \\
\hline Karlodinium veneficum & 11.0 & Storeatula major & 5.6 & 2.0 & 20 & 250 & 0.520 & 0.13 & 7.50 & (2) \\
\hline Gyrodinium galatheanum & 11.0 & Storeatula major & 5.6 & 2.0 & 20 & 100 & 0.940 & 0.12 & & (3) \\
\hline Paragymnodinium shiwhaense & 12.4 & Teleaulax sp. & 5.6 & 2.2 & 20 & 20 & 1.097 & 0.38 & 0.7 & (4) \\
\hline Prorocentrum donghaiense & 13.2 & Teleaulax sp. & 5.6 & 2.4 & 20 & 20 & 0.510 & 0.03 & 0.04 & (5) \\
\hline Karlodinium armiger & 16.7 & Rhodomonas baltica & 10.7 & 1.6 & 15 & 180 & 0.650 & 0.97 & 10.80 & (6) \\
\hline Gymnodinium aureolum & 19.4 & Teleaulax sp. & 5.6 & 3.5 & 20 & 20 & 0.169 & 0.06 & 0.003 & (7) \\
\hline Cochlodinium polykrikoides & 25.8 & Teleaulax sp. & 5.6 & 4.6 & 20 & 50 & 0.324 & 0.16 & 0.33 & (8) \\
\hline Prorocentrum micans & 26.6 & Teleaulax sp. & 5.6 & 4.8 & 20 & 20 & 0.197 & 0.04 & 0.05 & (5) \\
\hline Ceratium furca & 29.0 & Natural prey populations & & & 11.5 & 100 & 0.600 & 3.55 & & (9) \\
\hline Gonyaulax polygramma & 32.5 & Teleaulax sp. & 5.6 & 5.8 & 20 & 50 & 0.278 & 0.18 & 0.18 & $(10)$ \\
\hline Dinophysis acuminata & 35.0 & Myrionecta rubra & 22.0 & 1.6 & 20 & 60 & 0.950 & & & (11) \\
\hline Lingulodinium polyedrum & 36.6 & Scrippsiella trochoidea & 25.1 & 1.5 & 20 & 50 & 0.303 & 0.36 & 0.14 & (5) \\
\hline Fragilidium subglobosum & 45.0 & Ceratium tripos & 59.5 & 0.8 & 15 & 45 & 0.500 & 6.27 & & $(12)$ \\
\hline Dinophysis norvegica & 45.0 & Natural prey populations & & & 10 & 67 & 0.630 & 2.59 & & (9) \\
\hline Dinophysis acuta & 48.5 & Natural prey populations & & & 10 & 67 & 0.410 & 1.49 & & (9) \\
\hline Fragilidium cf. mexicanum & 54.5 & Lingulodinium polyedrum & 37.9 & 1.4 & 22 & 20 & 0.360 & 7.00 & 6.00 & $(13)$ \\
\hline
\end{tabular}

Note. (1): Jakobsen et al. (2000), (2): Adolf et al. (2006), (3): Li et al. (2000), (4): Yoo et al. (2010), (5): Jeong et al. (2005c), (6): Berge et al. (2008), (7): Jeong et al. (2010), (8): Jeong et al. (2004c), (9): Granéli et al. (1997), (10): Jeong et al. (2005d), (11): Park et al. (2006), (12): Hansen and Nielsen (1997), (13): Jeong et al. (1999a). *: Heterotrophic dinoflagellate conducting mixotrophy using kleptoplastids from prey cells. 
Table 5. Optimal prey and maximum growth, ingestion, and clearance rates of each heterotrophic dinoflagellate predator species

(ESD: Equivalent spherical diameter $(\mu \mathrm{m})$, FM: Feeding mechanism, DE: Direct engulfment, PD: Peduncle, PL: Pallium, Tx: Taxon, RPP: Ratio of predator to prey ESD, T: Temperature $\left({ }^{\circ} \mathrm{C}\right)$, MGR: Maximum growth rate $\left(\mathrm{d}^{-1}\right)$, MIR: Maximum ingestion rate (ng $\mathrm{C}$ grazer $^{-1} \mathrm{~d}^{-1}$ ), MCR: Maximum clearance rate $\left(\mu l\right.$ grazer $\left.^{-1} \mathrm{~h}^{-1}\right)$, BL: Blood, CR: Cryptophyte, DA: Diatom, DN: Dinoflagellate, RA: Raphidophyte, *: prey species for supporting MGR and MIR of Polykrikos kofoidii were different)

\begin{tabular}{|c|c|c|c|c|c|c|c|c|c|c|}
\hline$\overline{\text { Predator }}$ & ESD & "FM Optimal Prey & T" Tx & ESD & RPP & $\overline{\mathrm{T}}$ & "MGR & MIR & $\overline{\mathrm{MCR}}$ & Ref. \\
\hline Gymnodinium sp. & 6.0 & DE Rhodomonas salina & $\mathrm{CR}$ & 8.0 & 0.8 & 15 & 0.936 & 0.04 & 0.05 & (1) \\
\hline Protoperidinium bipes & 7.8 & PL Skeletonema costatum & DA & 5.9 & 1.3 & 20 & 1.370 & 2.9 & 1.00 & (2) \\
\hline Protoperidinium hirobis & 8.7 & PL Leptocylindrum danicus & DA & 19.7 & 0.4 & 20 & 1.230 & 0.8 & 0.50 & (3) \\
\hline Luciella masanensis & 13.5 & PD perch bloods & $\mathrm{BL}$ & 6.1 & 2.2 & 20 & 1.460 & 2.6 & 0.83 & (4) \\
\hline Pfiesteria piscicida & 13.5 & PD perch bloods & $\mathrm{BL}$ & 6.1 & 2.2 & 20 & 1.740 & 4.3 & 2.50 & (5) \\
\hline Stoeckeria algicida & 13.9 & PD Heterosigma akashiwo & RA & 11.5 & 1.2 & 20 & 1.630 & 0.8 & 3.70 & (6) \\
\hline Oxyrrhis marina & 15.6 & DE Heterosigma akashiwo & RA & 11.5 & 1.4 & 20 & 1.430 & 1.3 & 0.30 & (7) \\
\hline Gyrodinium dominans & 20.0 & DE Skeletonema costatum & $\mathrm{DN}$ & 5.4 & 3.7 & 24 & 0.370 & - & & (8) \\
\hline Protoperidinium vorax & 21.0 & PL Sk. pseudocostatum & DA & 4.0 & 5.3 & 20 & 1.090 & 2.3 & 19.90 & (9) \\
\hline Oblea rutunda & 21.6 & PL Ditylum brightwellii & DA & 33.0 & 0.7 & 20 & 0.660 & 1.3 & 0.70 & $(10)$ \\
\hline Protoperidinium steinii & 25.8 & PL Heterocapsa triquetra & DN & 15.0 & 1.7 & 15 & 0.180 & & & (11) \\
\hline Protoepridinium huberi & 26.5 & PL Ditylum brightwellii & DA & 26.5 & 1.0 & 20 & 0.720 & 17.8 & 23.00 & (12) \\
\hline Diplopsalis lenticula & 31.0 & PL Ditylum brightwellii & DA & 35.2 & 0.9 & 15 & 0.250 & 19.4 & 2.70 & (13) \\
\hline Gyrodinium spirale & 31.8 & DE Prorocentrum minimum & DN & 12.1 & 2.6 & 20 & 0.790 & 13.6 & 5.30 & (14) \\
\hline Protoperidinium excentricum & 35.8 & PL Ditylum brightwellii & DA & 35.2 & 1.0 & 12 & 0.330 & & & $(15)$ \\
\hline Protoperidinium pellucidum & 36.1 & PL Ditylum brightwellii & DA & 26.5 & 1.4 & 20 & 0.700 & 11.5 & & $(16)$ \\
\hline Polykrikos kofoidii* & 43.5 & DE Gymnodinium catenatum & $\mathrm{DN}$ & 34.0 & 1.3 & 20 & 1.120 & 17.1 & 4.60 & $(17)$ \\
\hline Polykrikos kofoidii* & 43.5 & DE Lingulodinium polyedrum & DN & 37.9 & 1.1 & 20 & 0.826 & 24.4 & 5.90 & $(17)$ \\
\hline Protoperidinium spiniferum & 45.0 & PL Leptocylindrum danicus & DA & 19.7 & 2.3 & 20 & 0.300 & & & (3) \\
\hline Protoperidinium conicum & 45.7 & PL Ditylum brightwellii & DA & 35.2 & 1.3 & 12 & 1.130 & 17.7 & & $(15)$ \\
\hline Protoperidinium pallidum & 46.6 & PL Ditylum brightwellii & DA & 35.2 & 1.3 & 15 & 0.280 & & & (11) \\
\hline Zygbikodinium lenticulatum & 50.0 & PL Ditylum brightwellii & DA & 35.2 & 1.4 & 15 & 0.200 & & & (11) \\
\hline Protoperidinium divergens & 61.0 & PL Lingulodinium polyedrum & $\mathrm{DN}$ & 38.2 & 1.6 & 19 & 0.484 & 12.0 & 0.67 & $(18)$ \\
\hline Protoperidinium crassipes & 73.0 & PL Lingulodinium polyedrum & DN & 36.6 & 2.0 & 19 & 0.308 & 5.3 & 0.47 & $(18)$ \\
\hline Protoperidinium depressum & 81.0 & PL Ditylum brightwellii & DA & 35.2 & 2.3 & 12 & 0.210 & 12.1 & & $(15)$ \\
\hline
\end{tabular}

Note. (1): Jakobsen and Hansen (1997), (2): Jeong et al. (2004d), (3): Jacobson and Anderson (1986), (4): Jeong et al. (2007a), (5): Jeong et al. (2006), (6): Jeong et al. (2005a), (7): Jeong et al. (2003a), (8): Nakamura et al. (1995), (9): Siano and Montresor (2005), (10): Strom and Buskey (1993), (11): Naustvoll (2000), (12): Buskey et al. (1994), (13): Naustvoll (1998), (14): Kim and Jeong (2004), (15): Menden-Deuer et al. (2005), (16): Buskey (1997), (17): Jeong et al. (2001b), (18): Jeong and Latz (1994)

Protoperidinium cf. divergens, while $P$. cf. divergens also feed on $F$. cf. mexicanum (Jeong et al. 1997). However, in general, $F$. cf. mexicanum predominates over $P$. cf. divergens in their competition even though their sizes are similar. Also, the engulfment feeding Oxyrrhis marina dominated over the peduncle feeding Pfiesteria piscicida, Stoeckeria algicida, and Luciella masanensis (Jeong et al. 2007c). Therefore, engulfment feeding may be a more effective feeding mechanism than pallium feeding or peduncle feeding if there are no supplementary tools such as nematocysts or trichocysts. Feeding mechanisms may be a critical factor determining predator and prey relationships among dinoflagellates and thus it is worthwhile exploring this topic further.

\section{Growth and Ingestion Rates}

The range of the growth and ingestion rates of dinoflagellates is very wide (Table $3,4,5)$. The growth and ingestion rates of dinoflagellates have been known to be affected by diverse factors; prey species and concentrations are primary factors affecting the rates (e.g. Jeong et al. 2007a). In this section, we examined whether the growth and ingestion rates of dinoflagellate predators are also affected by size, trophic mode, or feeding mechanisms of the predators or not.

\section{4a. Predator size effect}

When the optimal prey for each dinoflagellate predator species was provided, MGRs of dinoflagellates growing autotrophically (ATDs) and HTDs were significantly 


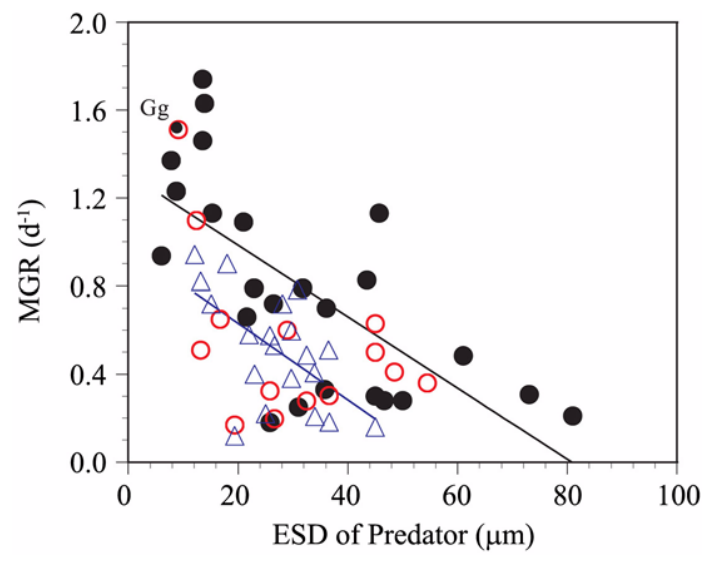

Fig. 4. The maximum growth rate (MGR, $\left.d^{-1}\right)$ of phototrophic dinoflagellates growing exclusively photosynthetically (open triangles) and growing mixotrophically (open circles) and heterotrophic dinoflagellates (closed circles) as a function of the size (Equivalent Spherical Diameters, ESD, $\mu \mathrm{m})$ of the predator when each predator fed on the optimal prey species (see Table 2, 3, 4). The equation of the regression was MGR $\left(\mathrm{d}^{-1}\right)=-0.017 \times($ ESD of predator $)$ $+9.80, r^{2}=0.351$ for autotrophic growth $(n=20, p<0.01)$; $\operatorname{MGR}\left(\mathrm{d}^{-1}\right)=-0.016 \times($ ESD of predator $)+1.31, \mathrm{r}^{2}=0.472$ for heterotrophic growth $(\mathrm{n}=25, \mathrm{p}<0.005)$. Gymnodinium gracilentum $(\mathrm{Gg})$ is a heterotrophic dinoflagellate conducting mixotrophy using kleptoplastids from prey cells and thus was treated as a MTD in this calculation. Temperature effect was not considered because optimal temperature for each dinoflagellate species is different from the other

negatively correlated with the predator size ( $\mathrm{p}<0.01$ for ATD and $\mathrm{p}<0.005$ for HTD; Fig. 4). However, MIRs of MTDs and HTDs were significantly positively correlated with the predator size ( $\mathrm{p}<0.01$ for MTD and $\mathrm{p}<0.05$ for HTD; Fig. 5). When single prey item was offered, feeding by dinoflagellates on some prey was affected by the predator size, while that on other prey was not; ingestion rates by MTDs and HTDs on heterotrophic bacteria $(\mathrm{ESD}<0.5 \mu \mathrm{m})$ were not significantly affected by the size of the predators (Seong et al. 2006; Jeong et al. 2008), while those on the cyanobacterium Synechococcus sp. $(\mathrm{ESD}=2 \mu \mathrm{m})$ were affected (Jeong et al. 2005b). Ingestion rates by engulfment feeding MTDs on an unidentified cryptophyte were also affected by the predator size (Jeong et al. 2005c). Thus, for the filter/interception feeding dinoflagellate predator (on heterotrophic bacteria), the shape (cingulum depression, displacement of the cingulum as described above) of the dinoflagellate predators may be more important than the size, while for engulfment feeding dinoflagellate predator (on larger algal prey), the size of the predator may be an important factor affecting the ingestion rates of the predators.

\section{4b. Trophic mode effect}

The highest MGR of the HTDs $\left(1.7 \mathrm{~d}^{-1}\right.$ for Pfiesteria piscicida; Jeong et al. 2006) is double the highest MGR of dinoflagellates growing autotrophically $\left(0.94 \mathrm{~d}^{-1}\right.$ for Prorocentrum minimum; Kondo et al. 1990) (Table 3, 4, 5). Also, MGRs of small HTDs are much higher than those of similar sized ATDs (Fig. 4). Energy gain of small HTDs through feeding may be higher than that of small ATDs through photosynthesis. Also, enzymes involved in photosynthesis may lower MGRs of dinoflagellates and it is worthwhile exploring this topic. The range of MIRs of each HTD was 0.04-24.4 ng C dinoflagellate ${ }^{-1} \mathrm{~d}^{-1}$, while that of each MTD species was 0.03-7.0 ng C dinoflagellate $\mathrm{d}^{-1}$ (Fig. 5). Also, MIRs of HTDs were higher than those of similar sized MTDs (Fig. 5). Heterotrophic activity of HTDs (feeding and digestion) is likely to be higher than that of MTDs. Based on these results, we suggest that to increase growth and ingestion rates, some MTDs may evolve to HTDs by discarding the plastids. It is worthwhile to explore the relationships between growth and ingestion rates of dinoflagellates and evolution.

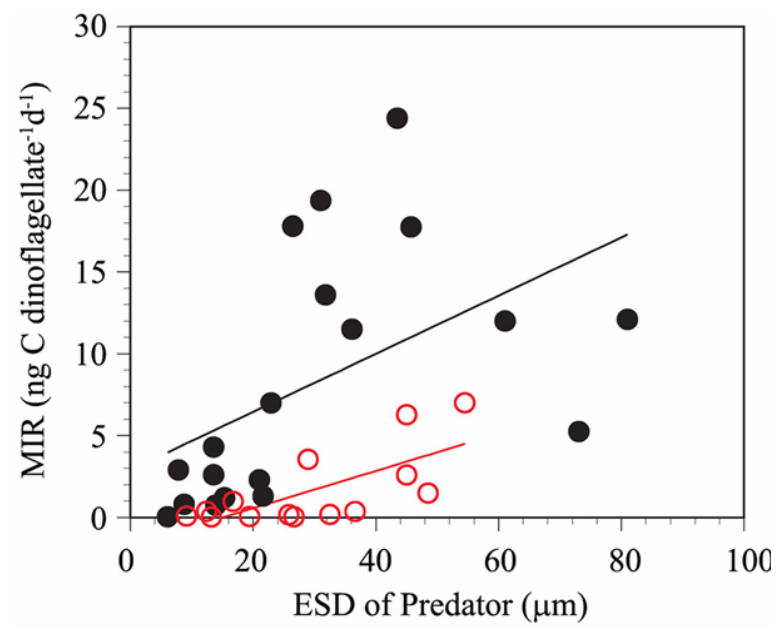

Fig. 5. The maximum ingestion rate (MIR, ng C dinoflagellate ${ }^{-1} d^{-1}$ ) of phototrophic dinoflagellates growing mixotrophically (open circles) and heterotrophic dinoflagellates (closed circles) as a function of the size (Equivalent Spherical Diameters, ESD, $\mu \mathrm{m})$ of the predator when each predator fed on the optimal prey species (see Table 4, 5). The equation of the regression was MIR (ng C dinoflagellate $\mathrm{d}^{-1}$ ) $=0.108 \times($ ESD of predator $)-1.49, \mathrm{r}^{2}=0.517$ for mixotrophs $(\mathrm{n}=16, \mathrm{p}<0.01)$; MIR (ng $\mathrm{C}$ dinoflagellate $\left.\mathrm{d}^{-1}\right)=0.178 \times$ (ESD of predator) $-2.89, \mathrm{r}^{2}=0.265$ for heterotrophs $(\mathrm{n}=16$, $\mathrm{p}<0.05$ ) 

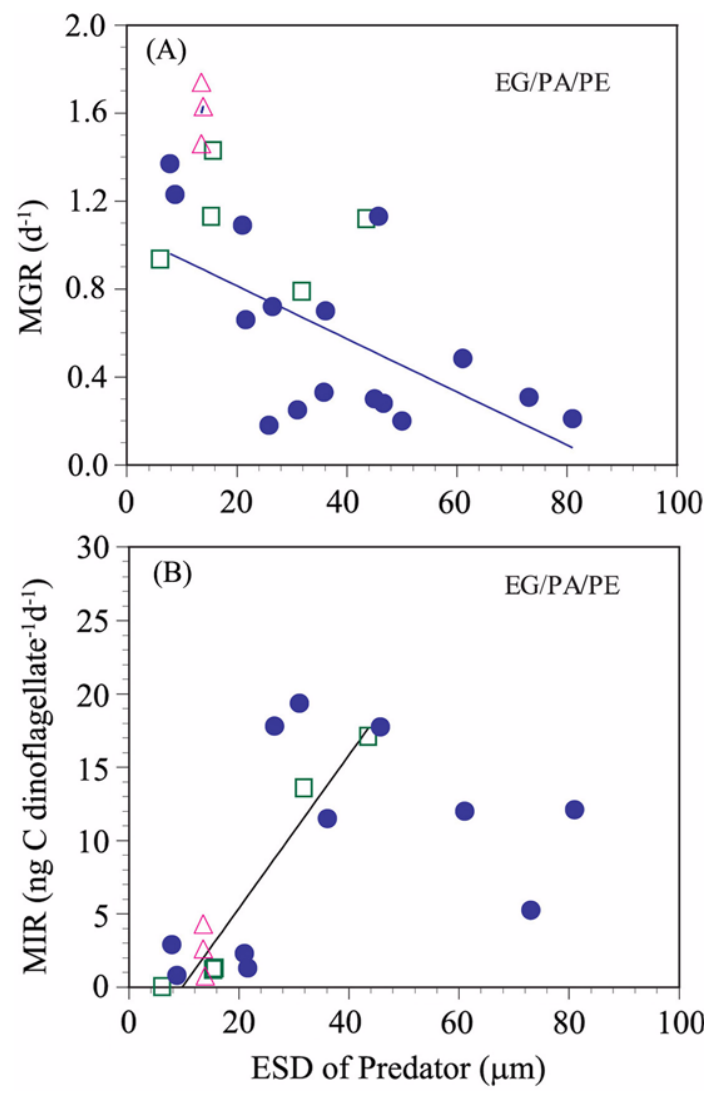

Fig. 6. The maximum growth (MGR, $\left.\mathrm{d}^{-1}, \mathrm{~A}\right)$ and ingestion rate (MIR, ng C dinoflagellate $\mathrm{d}^{-1} \mathrm{~d}^{-1}, \mathrm{~B}$ ) of heterotrophic dinoflagellates having different feeding mechanisms as a function of the size (Equivalent Spherical Diameters, ESD, $\mu \mathrm{m}$ ) of the predator when each predator fed on the optimal prey species (see Table 5). Pink triangles: Peduncle feeders (PE). Green squares: Direct engulfment feeders (EG). Blue circles: Pallium feeders (PA). The equation of the regression for PA in (A) was MGR $\left(\mathrm{d}^{-1}\right)=$ $-0.012 \times($ ESD of predator $)+1.06, \mathrm{r}^{2}=0.382(\mathrm{n}=16, \mathrm{p}<0.05)$; The equation of the regression for EG in (B) was MIR (ng C dinoflagellate $\left.\mathrm{d}^{-1}\right)=0.523 \times(\mathrm{ESD}$ of predator $)-5.09$, $r^{2}=0.944$ for mixotrophs $(n=5, p<0.05)$

\section{4c. Feeding mechanism effect}

When the predators' ESDs were $<21 \mu \mathrm{m}$, the mean of the 3 highest MGRs of the peduncle feeders (Pfiesteria piscicida, Stoeckeria algicida, and Luciella masanensis) was significantly higher than that of the engulfment feeding HTDs (Oxyrrhis marina, Gymnodinium sp., and Gyrodinium dominans) and the pallium feeding HTDs (Protoperidinium bipes, $P$. hirobis, and $P$. vorax $)(\mathrm{p}<0.05$ for both, one-tailed t-test) which were not significantly different from each other ( $\mathrm{p}>0.1$, two-tailed t-test) (Fig. 6A). To the contrary, the mean of the 2 highest MIRs of the peduncle feeders was significantly lower than that of the engulfment feeders and the pallium feeders $(p<0.05$, one-tailed t-test) which were not significantly different from each other $(\mathrm{p}>0.1$, two-tailed t-test) (Fig. 6B). Therefore, the growth efficiency of the peduncle feeders is higher than that of the engulfment feeders or the pallium feeders; The peduncle feeding HTDs may spend less energy cost to feed, ingest, and grow compared to the engulfment feeding or the pallium feeding HTDs. Engulfing a prey cell may spend large energy in opening and closing the sulcus or the apical horn, the suture using microtubletes. Also, the pallium feeding may spend large energy in towing and handling large prey cells and in form large pallium. However, the peduncle feeding HTD may just form tiny feeding tube and suck prey materials.

\section{4d. Optimal prey size}

When the MGR of each dinoflagellate species on its optimal prey was achieved, the range of the ratios of MTD predator to prey size $(0.8-5.8)$ is similar to that of HTD predator to prey size (0.4-5.3) (Fig. 7A and B). The high MGRs (i.e. $>0.8 \mathrm{~d}^{-1}$ for MTDs and $>1.2 \mathrm{~d}^{-1}$ for HTDs) were obtained when the ratios for MTDs and HTDs were 1.1-2.4 and $0.4-2.2$, respectively. The ratios of predator to prey size when the 3 highest MGRs were achieved were 0.4-1.3 for the pallium feeding HTDs, 1.3-1.4 for the engulfment feeding HTDs, and 1.2-2.2 for the peduncle feeding HTDs (Fig. 7B). The lowest ratio was achieved by the pallium feeding HTDs because they are able to feed on prey larger than themselves (e.g. Naustvoll 2000).

When the high MIRs (i.e. $>5 \mathrm{ng} \mathrm{C}$ dinoflagellate $\mathrm{d}^{-1}$ for MTDs and $>10 \mathrm{ng} C$ dinoflagellate $\mathrm{d}^{-1}$ for HTDs) were obtained, the range of the ratios of HTDs predator to prey size (0.9-2.6) was wider than that of MTDs (0.8-1.4) (Fig. 7C-D). When the 2 highest MIRs were achieved, the ratios of predator to prey size of pallium feeding HTDs (0.9-1.0) were markedly lower than those of peduncle feeding HTDs (1.2-2.2). Therefore, the highest MIRs were achieved when the pallium feeding HTDs fed on prey similar to themselves, while the peduncle feeders feed on prey having half the size of the predators. Therefore, the optimal ratios of predator to prey size of dinoflagellates are affected by the types of the feeding mechanisms, which may cause separation of ecological niches of the dinoflagellates.

\section{4e. Light and nutrient effects}

In addition to the biological factors, light and nutrient conditions sometimes affect the ingestion rates of MTDs; 

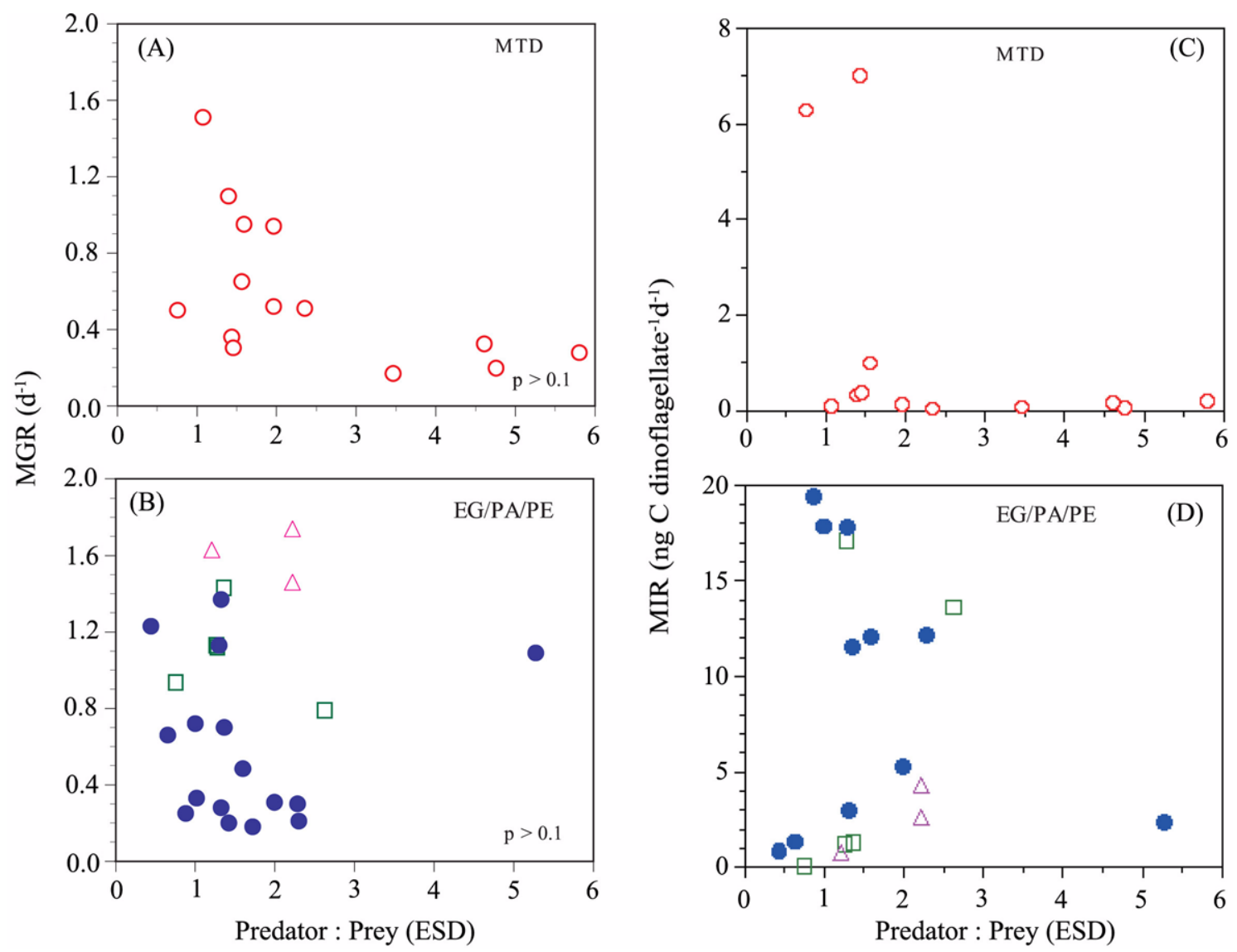

Fig. 7. The maximum growth $\left(\mathrm{d}^{-1}\right)$ and ingestion rates (MIR, ng C dinoflagellate $\left.\mathrm{d}^{-1} \mathrm{~d}^{-1}\right)$ of mixotrophic $(\mathrm{A}, \mathrm{C})$ and heterotrophic dinoflagellates having different feeding mechanisms (B, D) as a function of the ratio of predator relative to prey size when each predator fed on the optimal prey species (see Table 5)

(Pink triangles: Peduncle feeders (PE), Green squares: Direct engulfment feeders (EG), Blue circles: Pallium feeders (PA))

the ingestion rates of the MTDs Fragilidium subglobosum, Gymnodinium gracilentum, and Karlodinium veneficum (previously Gyrodinium galatheanum and Karlodinium micrum) increased continuously, or increased and then were saturated, with increasing light intensity up to ca. $75-100 \mu \mathrm{E}$ $\mathrm{m}^{-2} \mathrm{~s}^{-1}$ (Skovgaard 1996b, 1998, Hansen and Nielsen 1997, Li et al. 2000, Skovgaard et al. 2000), while those of $F$. cf. mexicanum (20-200 $\mu \mathrm{E} \mathrm{m}^{-2} \mathrm{~s}^{-1}$, Jeong et al. 1999a) and $P$. minimum (between $6 \%$ and $100 \%$ incident light intensity; Stoecker et al. 1997) were not significantly affected by light intensity under the provided conditions. The ingestion rates of Ceratium furca and $K$. veneficum were also affected by nutrient conditions ( $\mathrm{Li}$ et al. 2000; Smalley et al. 2003), while that of $F$. cf. mexicanum (Jeong et al. 1999a) was not significantly affected by nutrient conditions. Therefore, the effects of light and nutrient conditions on feeding in MTDs may depend on the species. Mixotrophy in phototrophic dinoflagellates, whose feeding is not affected by light and nutrient conditions, may enable the dinoflagellates to have an advantage in surviving using photosynthesis when the abundance of prey is low, while mixotrophy in phototrophic dinoflagellates, whose feeding is affected by light and nutrient conditions, may enable the dinoflagellates to have an advantage in surviving, using phagotrophy when light and nutrient conditions are not favorable for photosynthesis. Therefore, light and nutrient conditions may be important driving forces on the evolution of trophic modes of MTDs.

\section{Grazing Impact by Dinoflagellates on the Natural Populations of Prey}

Dinoflagellate predators often have considerable grazing impact on and sometimes control the natural population of prey including heterotrophic bacteria (Seong et al. 2006; Jeong et al. 2008), cyanobacteria (Jeong et al. 2005b), nanoflagellates (Jeong et al. 2007b), diatoms (Jeong et al. 
2004d; Yoo et al. 2009), other dinoflagellates (Jeong et al. 2005c), and ciliates (Smalley and Coats 2002). In general, the grazing impact by MTDs and HTDs on a population of co-occurring prey increased with increasing the abundance of the dinoflagellate predators. The ingestion rates and also grazing impact by dinoflagellates on bacteria are comparable to those by mixotrophic nanoflagellates (MNF) or HNFs because the abundance of the former predators is also comparable to that of the nanoflagellates (Seong et al. 2006; Jeong et al. 2005b, 2008). However, the abundance of dinoflagellates is usually much higher than that of ciliates or copepods. Therefore, even though the ingestion rates of dinoflagellates are lower than that of ciliates and copepods, grazing impact of the former predators on natural population of prey are usually higher than that of the latter predators. For example, grazing coefficients attributable to Acartia spp. on Prorocentrum minimum in the Korean coastal waters $\left(0-0.001 \mathrm{~h}^{-1}\right)$ are much lower than those for Gyrodinium dominans on co-occurring P. minimum $\left(0-0.07 \mathrm{~h}^{-1}\right)$ or for $G$. spirale $\left(0-0.23 \mathrm{~h}^{-1}\right)$ (e.g. Kim and Jeong 2004). Much lower abundances of Acartia spp. (0.01-0.40 ind. $\left.1^{-1}\right)$ compared to those of Gyrodinium spp. $\left(1,600-140,000\right.$ ind. $\left.1^{-1}\right)$ may be responsible for these lower grazing coefficients, even though the ingestion rates of Acartia spp. on P. minimum $\left(10,900 \mathrm{ng} \mathrm{C}\right.$ grazer $\left.{ }^{-1} \mathrm{~d}^{-1}\right)$ are much higher than that of Gyrodinium spp. (1-14 ng C grazer $\left.\mathrm{d}^{-1}\right)$. Therefore, when investigating the population dynamics of target prey, we must measure the grazing impact by dinoflagellate predators.

\section{Mortality due to Predation}

To explore the population dynamics of dinoflagellates, the mortality rate due to predation in addition to the growth rate should be obtained. Other MTDs (Jeong et al. 2005c), HTDs (Hansen 1991), ciliates (Jeong et al. 1999b), copepods (Berggreen et al. 1988; Jeong 1994a; Kim and Jeong 2004;

Table 6. Maximum ingestion and clearance rates of heterotrophic dinoflagellates (HTD) on mixotrophic (MTD) and HTDs

(RPP: Ratio of predator to prey ESD, T: Temperature $\left({ }^{\circ} \mathrm{C}\right)$, MIR: Maximum ingestion rate (ng $\mathrm{C}$ grazer $\mathrm{d}^{-1}$ ), MCR: Maximum clearance rate $\left(\mu\right.$ grazer $\left.^{-1} h^{-1}\right)$, ESD: Equivalent spherical diameter $(\mu \mathrm{m}), *$ : Highest MIR and MCR of each predator species)

\begin{tabular}{|c|c|c|c|c|c|c|c|c|c|}
\hline Predator & ESD & Prey & Taxon & ESD & RPP & $\overline{\mathrm{T}}$ & MIR & "MCR & Ref. \\
\hline Luciella masanensis & 13.5 & Amphidinium carterae & MTD & 9.7 & 1.4 & 20 & $0.3^{*}$ & $0.06^{*}$ & (1) \\
\hline Pfiesteria piscicida & 13.5 & Heterocapsa rotundata & MTD & 5.8 & 2.3 & 20 & 0.2 & 0.01 & (2) \\
\hline Pfiesteria piscicida & 13.5 & Amphidinium carterae & MTD & 9.7 & 1.4 & 20 & $1.1^{*}$ & $1.50^{*}$ & (2) \\
\hline Pfiesteria piscicida & 13.5 & Akashiwo sanguinea & MTD & 30.8 & 0.4 & 20 & 0.1 & 0.01 & (2) \\
\hline Pfiesteria piscicida & 13.5 & Gymnodinium catenatum & MTD & 33.9 & 0.4 & 20 & 0.2 & 0.01 & (2) \\
\hline Gyrodinium dominans & 15.3 & Prorocentrum minimum & MTD & 12.1 & 1.3 & 20 & 1.2 & $0.90^{*}$ & (3) \\
\hline Oxyrrhis marina & 15.6 & Amphidinium carterae & MTD & 9.7 & 1.6 & 20 & 2.8 & 2.40 & (4) \\
\hline Oxyrrhis marina & 15.6 & Karlodinium veneficum & MTD & 9.1 & 1.7 & 20 & $5.5^{*}$ & $2.40^{*}$ & (5) \\
\hline Oxyrrhis marina & 15.6 & Prorocentrum minimum & MTD & 12.1 & 1.3 & 20 & 2.0 & 0.80 & (6) \\
\hline Gyrodinium dominans & 20.0 & Heterocapsa triquetra & MTD & 15.3 & 1.3 & 24 & $7.5^{*}$ & 0.19 & (7) \\
\hline Gyrodinium spirale & 28.0 & Heterocapsa triquetra & MTD & 15.8 & 1.8 & 15 & 7.5 & 0.30 & (8) \\
\hline Gyrodinium spirale & 31.8 & Prorocentrum minimum & MTD & 12.1 & 2.6 & 20 & $13.6^{*}$ & $5.30 *$ & (3) \\
\hline Protoperidinium pellucidum & 36.1 & Prorocentrum micans & MTD & 32.7 & 1.1 & 20 & $7.7^{*}$ & & (9) \\
\hline Polykrikos kofoidii & 43.5 & Gymnodinium catenatum & MTD & 34.0 & 1.3 & 20 & 17.1 & 4.60 & $(10)$ \\
\hline Polykrikos kofoidii & 43.5 & Scrippsiella trochoidea & MTD & 25.1 & 1.7 & 20 & 16.6 & 1.10 & (10) \\
\hline Polykrikos kofoidii & 43.5 & Lingulodinium polyedrum & MTD & 37.9 & 1.1 & 20 & $24.4^{*}$ & $5.90^{*}$ & $(10)$ \\
\hline Polykrikos kofoidii & 43.5 & Ceratium furca & MTD & 29.0 & 1.5 & 20 & 9.8 & 3.70 & $(10)$ \\
\hline Polykrikos kofoidii & 43.5 & Prorocentrum micans & MTD & 26.0 & 1.7 & 20 & 4.6 & 2.30 & $(10)$ \\
\hline Polykrikos kofoidii & 43.5 & Gyrodinium impudicum & MTD & 23.2 & 1.9 & 20 & 5.4 & 1.30 & (10) \\
\hline Protoperidinium divergens & 61.0 & Lingulodinium polyedrum & MTD & 38.2 & 1.6 & 19 & $12.0 *$ & $0.67 *$ & (11) \\
\hline Protoperidinium crassipes & 73.0 & Lingulodinium polyedrum & MTD & 36.6 & 2.0 & 19 & $5.3^{*}$ & $0.47 *$ & (11) \\
\hline Oxyrrhis marina & 15.6 & Pfiesteria piscicida & HTD & 13.5 & 1.2 & 20 & $0.3^{*}$ & $0.34 *$ & (12) \\
\hline Oxyrrhis marina & 15.6 & Stoeckeria algicida & HTD & 13.5 & 1.2 & 20 & 0.1 & 0.61 & (12) \\
\hline Oxyrrhis marina & 15.6 & Luciella masanensis & HTD & 13.5 & 1.2 & 20 & 0.1 & 0.01 & (12) \\
\hline
\end{tabular}

Note. (1): Jeong et al. (2007a), (2): Jeong et al. (2006), (3): Kim and Jeong (2004), (4): Jeong et al. (2001a), (5): Adolf et al. (2007), (6): Lee (1998), (7): Nakamura et al. (1995), (8): Hansen (1992), (9): Buskey (1997), (10): Jeong et al. (2001b), (11): Jeong and Latz (1994), (12): Jeong et al. (2007b) 
Table 7. Maximum ingestion and clearance rates of ciliates on mixotrophic (MTD) and heterotrophic dinoflagellate prey (HTD)

(T: Temperature $\left({ }^{\circ} \mathrm{C}\right)$, MIR: Maximum ingestion rate $\left(\right.$ ng C grazer $\left.{ }^{-1} \mathrm{~d}^{-1}\right), \mathrm{MCR}$ : Maximum clearance rate $\left(\mu l\right.$ grazer $\left.^{-1} \mathrm{~h}^{-1}\right), \mathrm{ESD}$ : Equivalent spherical diameter $(\mu \mathrm{m}), *$ : Highest MIR and MCR of each predator species)

\begin{tabular}{|c|c|c|c|c|c|c|c|c|c|}
\hline$\overline{\text { Predator }}$ & ESD & Prey & Taxon & ESD & RPP & $\overline{\mathrm{T}}$ & MIR & "MCR & Ref. \\
\hline Balanion sp. & 32 & Heterocapsa triquetra & MTD & 15.0 & 2.1 & 15 & $20 *$ & $1.2 *$ & (1) \\
\hline Tiarina fusus & 37 & Lingulodinium polyedrum & MTD & 37.9 & 1.0 & 19 & $23^{*}$ & $4.5^{*}$ & (2) \\
\hline Tiarina fusus & 37 & Scrippsiella trochoidea & MTD & 25.1 & 1.5 & 19 & 10 & 0.2 & (2) \\
\hline Tiarina fusus & 37 & Prorocentrum minimum & MTD & 12.8 & 2.9 & 19 & 2 & 0.2 & (2) \\
\hline Tiarina fusus & 37 & Amphidinium carterae & MTD & 16.1 & 2.3 & 19 & 3 & 0.01 & (2) \\
\hline Tiarina fusus & 37 & Heterocapsa triquetra & MTD & 12.8 & 2.9 & 19 & 3 & 0.0 & (2) \\
\hline Tiarina fusus & 37 & Prorocentrum micans & MTD & 26.0 & 1.4 & 19 & 3 & 0.4 & (2) \\
\hline Favella sp. & 72 & Heterocapsa triquetra & MTD & 15.0 & 4.8 & 15 & 130 & 11.4 & (1) \\
\hline Favella sp. & 74 & Scrippsiella trochoidea & MTD & 26.5 & 2.8 & 20 & $237^{*}$ & $43.0^{*}$ & (1) \\
\hline Strombidinopsis sp. & 102 & Cochlodinium polykrikoides & MTD & 23.3 & 4.4 & 19 & $353^{*}$ & 52.3 & (3) \\
\hline Strombidinopsis sp. & 102 & Gymnodinium sanguineum & MTD & 36.3 & 2.8 & 19 & 343 & 85.6 & (3) \\
\hline Strombidinopsis sp. & 102 & Prorocentrum minimum & MTD & 12.8 & 8.0 & 19 & 267 & $110.0^{*}$ & (3) \\
\hline Strombidinopsis sp. & 102 & Lingulodinium polyedrum & MTD & 37.9 & 2.7 & 19 & 222 & 110.0 & (3) \\
\hline Strombidinopsis sp. & 102 & Scrippsiella trochoidea & MTD & 25.1 & 4.1 & 19 & 207 & 41.0 & (3) \\
\hline Strombidinopsis jeokjo & 94 & Gyrodinium dominans & HTD & 15.3 & 6.1 & 20 & $108^{*}$ & $14.5^{*}$ & (4) \\
\hline Strombidinopsis jeokjo & 94 & Oxyrrhis marina & HTD & 15.6 & 6.0 & 20 & 87 & 13.4 & (4) \\
\hline Strombidinopsis jeokjo & 94 & Pfiesteria piscicida & HTD & 13.5 & 6.9 & 20 & 44 & 15.4 & (5) \\
\hline Strombidinopsis jeokjo & 94 & Stoeckeria algicida & HTD & 13.5 & 6.9 & 20 & 49 & 6.6 & (5) \\
\hline Strombidinopsis jeokjo & 94 & Luciella masanensis & HTD & 13.5 & 6.9 & 20 & 10 & 5.4 & (5) \\
\hline
\end{tabular}

Note. (1): Stoecker and Evans (1985), (2): Jeong et al. (2002), (3): Jeong et al. (1999), (4): Jeong et al. (2004b), (5): Jeong et al. (2007c)

Verity and Paffenhöfer 1996), larvae of mussels (Jeong et al. 2004a) and polychaeta (Song and Jeong unpubl. data; Watras et al. 1985), rotifers (Heinbokel et al. 1988), and larval fish (Scura and Jerde 1977) have been known to feed on MTDs. Also, HTDs were fed by MTDs (Jeong et al. 1997), other HTDs, ciliates (Jeong et al. 2004b; Stoecker et al. 2002) and copepods (Koski and Riser 2006). However, there has been no report on the feeding by larvae of mussels and polychaeta and rotifers on HTDs yet and it is worthwhile to explore this topic. The range of the ingestion rates of heterotrophic protistian and metazoan predators on MTDs and HTDs is very wide because the taxonomical characteristics, the size, and feeding mechanisms of these predators are diverse and the morphological and biochemical properties of MTD and HTD prey are also diverse.

\section{6a. Predation rates of diverse predators}

There have been many studies on ingestion rates of heterotrophic protists and metazoans on MTDs (Table 6, 7, 8). The maximum ingestion rates (MIRs) of HTD species on the optimal MTDs (0.3-24.4 ng C grazer $\left.{ }^{-1} \mathrm{~d}^{-1}\right)$ was comparable to that of the small ciliates $(<40 \mu \mathrm{m}$ in body length; $20-23$ $n g$ grazer $\left.^{-1} \mathrm{~d}^{-1}\right)$, but markedly lower than that of the larva of the mussel Mytilus galloprovincialis (69 $\mathrm{ng} \mathrm{C}$ grazer $^{-1} \mathrm{~d}^{-1}$ ) or large ciliates (130-350 ng C grazer $\left.\mathrm{r}^{-1} \mathrm{~d}^{-1}\right)$ (Table 6,7). MIRs of the copepod species on MTDs (0.1-73.6 $\mu \mathrm{g} \mathrm{C}$ copepod $\left.^{-1} \mathrm{~d}^{-1}\right)$ were ca. 10-1000 times higher than those of heterotrophic protists (Table 8). The maximum clearance rates (MCRs) of HTDs, ciliates, and metazoans on MTDs showed a pattern similar to MIRs; MCRs of the HTD species on MTDs (0.01-5.9 $\mu$ grazer $\left.^{-1} \mathrm{~h}^{-1}\right)$ was comparable to that of the small ciliates $\left(0.01-4.5 \mu 1\right.$ grazer $\left.^{-1} h^{-1}\right)$, but lower than that of the larva of M. galloprovincialis $(11.4 \mu \mathrm{l}$ grazer $\left.{ }^{-1} \mathrm{~h}^{-1}\right)$, large ciliates (11.4-110.0 $\mu 1$ grazer $\left.^{-1} \mathrm{~h}^{-1}\right)$, or the lava of the ploychaeta Polydora sp. $\left(520 \mu 1\right.$ grazer $^{-1} h^{-1}$; Watras et al. 1985) (Table 6,7). MCRs of copepods on MTDs (0.3-5.0 ml grazer $\left.{ }^{-1} \mathrm{~h}^{-1}\right)$ were also ca. 10-1000 times higher than those of heterotrophic protists (Table 8). Therefore, in MIRs and MCRs of the predators on MTDs, the general sequence was copepods $>$ large ciliates $=$ the larvae of benthos $>$ small ciliates $=$ HTDs.

There have been only a few studies on feeding by other HTDs or ciliates on HTDs (Jeong et al. 2004b, 2007c). The MIR of the HTD Oxyrrhis marina on HTDs (0.3 ng C grazer $\left.\mathrm{d}^{-1}\right)$ was much lower than that of the large ciliate Strombidinopsis jeokjo (108 ng C grazer $\left.{ }^{-1} \mathrm{~d}^{-1}\right)($ Table 6, 7). 
Table 8. Maximum ingestion and clearance rates of copepods on mixotrophic (MTD) and heterotrophic dinoflagellates (HTD)

(T: Temperature $\left({ }^{\circ} \mathrm{C}\right)$, MIR: Maximum ingestion rate $\left(\mu \mathrm{g} \mathrm{C}\right.$ copepod $\left.^{-1} \mathrm{~d}^{-1}\right)$, MCR: Maximum clearance rate $\left(\mathrm{ml} \mathrm{copepod}^{-1} \mathrm{~h}^{-1}\right)$, ESD: Equivalent spherical diameter $(\mu \mathrm{m}), *$ : Highest MIR and MCR of each predator species)

\begin{tabular}{|c|c|c|c|c|c|c|c|}
\hline Predator & Prey & Taxon & ESD & $\bar{T}$ & MIR & $\overline{\mathrm{MCR}}$ & Ref. \\
\hline Acartia tonsa & Amphidinium carterae & MTD & 9.7 & 20 & 3.5 & & $(1)$ \\
\hline Acartia tonsa & Prorocentrum minimum & MTD & 12.0 & 20 & 10.0 & 3.5 & $(2)$ \\
\hline Acartia tonsa & Gymnodinium sanguineum & MTD & 28.0 & 20 & 3.2 & 5.0 & (3) \\
\hline Acartia tonsa & Prorocentrum minimum & MTD & 12.6 & 20 & $19.7 *$ & & $(4)$ \\
\hline Acartia tonsa & Amphidinium carterae & MTD & 9.7 & 20 & 6.1 & & $(4)$ \\
\hline Acartia tonsa & Karenia brevis & MTD & 20.4 & 21 & 3.8 & & $(5)$ \\
\hline Calanus sinicus & Alexandrium tamarense (toxic) & MTD & 30.0 & 18 & $0.1^{*}$ & 4.0 & $(6)$ \\
\hline Calanus sinicus & Akexandrium tamarense (non-toxic) & MTD & 30.0 & 18 & - & 1.8 & $(6)$ \\
\hline Calanus helgolandicus & Prorocentrum micans & MTD & 30.0 & 15 & $73.6^{*}$ & 1.7 & $(7)$ \\
\hline Paracalanus crassirostris & Alexandrium tamarense (toxic) & MTD & 30.0 & 18 & & 0.5 & $(6)$ \\
\hline Paracalanus crassirostris & Alexandrium tamarense (non-toxic) & MTD & 30.0 & 18 & & 0.6 & $(6)$ \\
\hline Paracalanus crassirostris & Prorocentrum dentatum & MTD & 14.5 & 18 & & 0.3 & $(6)$ \\
\hline Temora turbinata & Karenia brevis & MTD & 20.4 & 21 & $23.4^{*}$ & & $(5)$ \\
\hline Temora turbinata & Prorocentrum minimum & MTD & 10.5 & 21 & & & $(5)$ \\
\hline Centropages typicus & Karenia brevis & MTD & 20.4 & 21 & $56.9 *$ & & $(5)$ \\
\hline Centropages typicus & Prorocentrum minimum & MTD & 10.5 & 21 & 0.1 & & $(5)$ \\
\hline Acartia spp.** & Oxyrrhis marina on $P$. minimum & HTD & 15.6 & 20 & $4.6^{*}$ & & $(8)$ \\
\hline Acartia spp.** & Oxyrrhis marina on Amphidinium carterae & HTD & 15.6 & 20 & 1.9 & & $(8)$ \\
\hline Acartia spp.** & Pfiesteria piscicida & HTD & 13.5 & 20 & 3.9 & 0.2 & $(9)$ \\
\hline Acartia spp.** & Stoecjeria algicida & HTD & 13.5 & 20 & 3.6 & 0.8 & $(9)$ \\
\hline Acartia spp.** & Luciella masanensis & HTD & 13.5 & 20 & 3.5 & 0.4 & $(9)$ \\
\hline Acartia tonsa & Oxyrrhis sp. & HTD & 13.9 & 20 & $5.0^{*}$ & & $(2)$ \\
\hline Acartia tonsa & Gyrodinium dominans (on Rhodomonas salina) & HTD & 14.6 & $17-20$ & & 2.0 & (3) \\
\hline Acartia tonsa & Gyrodinium dominans (on T. pseudonana) & HTD & 14.6 & $17-20$ & 1.0 & 2.5 & (3) \\
\hline Acartia tonsa & Pfiesteria piscicida & HTD & 10.0 & 20 & 4.8 & 1.4 & $(4)$ \\
\hline
\end{tabular}

Note. (1): Houde and Roman (1987), (2): Besiktepe and Dam (2002), (3): Broglio et al. (2003), (4): Roman et al. (2006), (5): Cohen et al. (2007), (6): Liu and Wang (2002), (7): Huskin et al. (2000), (8): Jeong et al. (2001a), (9): Jeong et al. (2007c). **: Acartia omorii \& A. hongi.

The MCR of $O$. marina on HTDs $\left(0.014 \mu 1\right.$ grazer $\left.^{-1} h^{-1}\right)$ was also much lower than that of $S$. jeokjo $\left(14.5 \mu 1\right.$ grazer $\left.^{-1} \mathrm{~h}^{-1}\right)$ (Table 6, 7). Large ciliates may be one of the major predators on HTDs. MIRs (0.7-5.0 $\mu \mathrm{g} \mathrm{C}$ copepod $\left.^{-1} \mathrm{~d}^{-1}\right)$ and MCRs (2.5-32.6 ml copepod $\left.{ }^{-1} h^{-1}\right)$ of the copepods on HTDs were also ca. 10-1000 times higher than those of heterotrophic protists (Table 6, 7, 8). To understand the population dynamics of HTDs, much more study on the mortality rate due to predators is necessary.

Calbet et al. (2003) showed that grazing by microzooplankton (several ciliates and rotifers) on the toxic MTD Alexandrium minutum was much higher than that by copepods. Higher abundance of microzooplankton than copepods might cause this difference. Therefore, when exploring mortality of dinoflagellates due to predation, we must measure feeding by both microzoolpankton and metazooplankton predators on dinoflagellates.

\section{6b. MTD prey vs HTD prey}

The growth and ingestion rates of the HTD Oxyrrhis marina on MTDs $(\mathrm{n}=3)$ were significantly higher than those on HTDs ( $<<0.05$, one tailed t-test; Fig. $8 \mathrm{~A}$ ). The ingestion rates of the large ciliate Strombidinopsis spp. $(\mathrm{n}=5)$ on MTDs were also significantly higher than those on HTDs $(\mathrm{p}<0.05$; Fig. $8 \mathrm{~B})$, even though the growth rates of Strombidinopsis spp. on MTDs were not significantly higher than those on HTDs ( $>0.1)$. The highest MIRs of the copepods Acartia spp. on MTDs were also clearly greater than those on HTDs (Fig. 8C). Therefore, compared to MTDs, HTDs may have more effective anti-predation tools against these predators. The maximum swimming speeds of HTDs (Pfiesteria piscicida, Stoeckeria algicida, and Luciella masanensis) were much higher than those of MTDs (Amphidinium carterae, Karlodinium veneficum, and Prorocentrum minimum). Higher swimming speeds of 

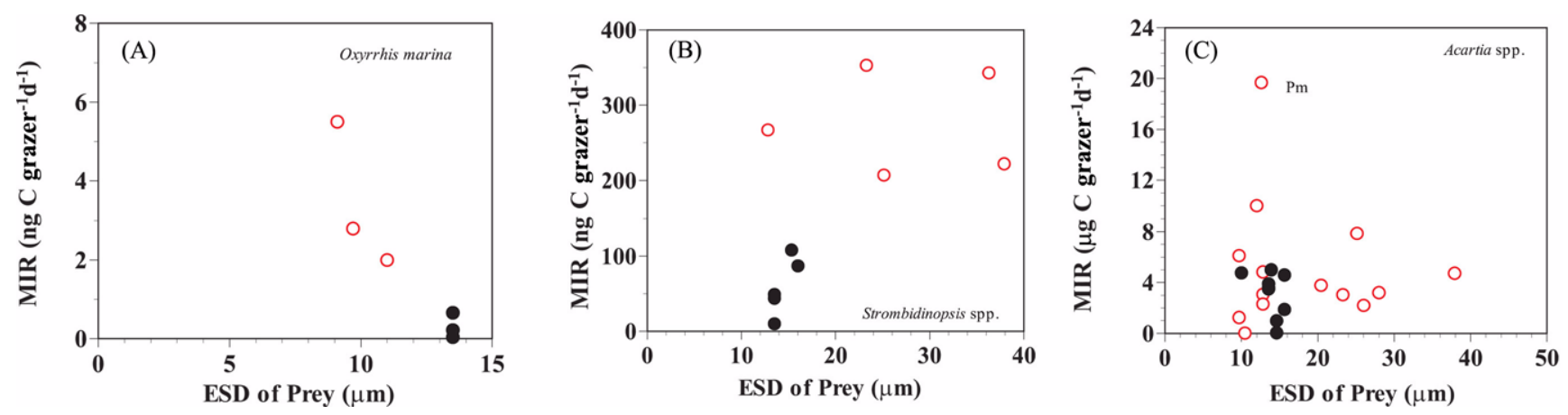

Fig. 8. The maximum ingestion rate (MIR, ng C grazer $^{-1} \mathrm{~d}^{-1}$ ) of the heterotrophic dinoflagellate Oxyrrhis marina (A), the ciliate Strombidinopsis spp. (B), and the copepods Acartia spp. (C) as a function of the size (Equivalent Spherical Diameters, ESD, $\mu \mathrm{m})$ when the predator fed on mixotrophic (open circles) and heterotrophic dinoflagellate prey (closed circles) (see Table 6, 7, 8). Pm: Prorocentrum minimum prey

the HTDs may escape from being captured by predators compared to MTDs. Also, these HTDs may attack the predators, while MTDs have been not known to attack the predators yet (Jeong et al. 2007c).

\section{6c. Toxic dinoflagellate prey}

Toxins of dinoflagellate prey may kill potential predators, be not eaten, or support the positive growth of predators; i) some Alexandrium strains caused loss of motility and cell lysis of the HTDs Oblea rotunda and Oxyrrhis marina by extracellular substances (Tillmann and John 2002). ii) a toxic strain of A.tamarense inhibited feeding by Favella spp. (Hansen 1995) and also the toxic naked dinoflagellate Gyrodinium aureolum suppresses the growth of $F$. ehrenbergii (Hansen 1989). Also, Strombidinopsis sp. and Tiarina fusus did not grow on the toxic dinoflagellate Amphidinium carterae (Jeong et al. 1999b, 2002). Some copepods have been known to reject some toxic MTDs (Huntley et al. 1983, 1986; Turner and Anderson 1983; Uye and Takamatsu 1990). However, whether or not copepods are able to ingest toxic MTDs is variable (reviewed by Turner and Tester 1997; Colin and Dam 2003). iii) However, a nontoxic strain of Alexandrium tamarense, the toxic dinoflagellates A. catenella and Dinophysis acuminata, were excellent prey for Favella spp. (Stoecker et al. 1981; Maneiro et al. 2000; Kamiyama and Arima 2001). Also, the HTD Polykrikos kofoidii exhibited a maximum growth rate on the toxic dinoflagellate Gymnodinium catenatum among diverse dinoflagellate prey. In addition, O. marina grew well on Amphidinium carterae (Jeong et al. 2001a). Therefore, it is concluded that feeding by heterotrophic protistan and metazoan predators on toxic dinoflagellates was affected by the prey species and strains of a toxic dinoflagellate and also the predator species.

In the ecological aspects, the presence of toxic dinoflagellates may determine the dominant heterotrophic protistan and metazoan predators. The predators which have strong bodies against cell lysis caused by phytotoxins of the toxic dinoflagellates and/or are able to feed on the toxic dinoflagellates (and detoxify the phytotoxins) may dominate zooplankton assemblages. If a predator detoxifies the phytotoxins, the predator plays the role of a sink of phytotoxins in marine food webs. Rapid division of a heterotrophic protistan predator may accelerate the detoxification by attenuating the phytotoxins inside a predator cell. Some copepods are known to transfer phytotoxins sometimes from toxic MTDs to higher level organisms such as fish, seabirds, and marine mammals (e.g. Tester et al. 2000). The copepods may tolerate the toxins during this transfer. However, a heterotrophic protistan predator may not play a role of a transfer of phytotoxins in marine food webs because it has weak tolerance for toxins, cannot detoxify, or cannot survive for a long time without eating prey.

\section{Red Tides or Harmful Blooms Dominated by Mixotrophic Dinoflagellates}

Many MTDs and some HTDs have been known to cause red tides or harmful blooms (e.g. Jeong 1995). There have been many studies on these red tides since the 19th century. However, for a long time, there have been some unsolved issues in red tides dominated by MTDs; (1) a mechanism of the outbreak and/or the persistence of red tides dominated by some MTDs such as Karenia brevis, Prorocentrum 


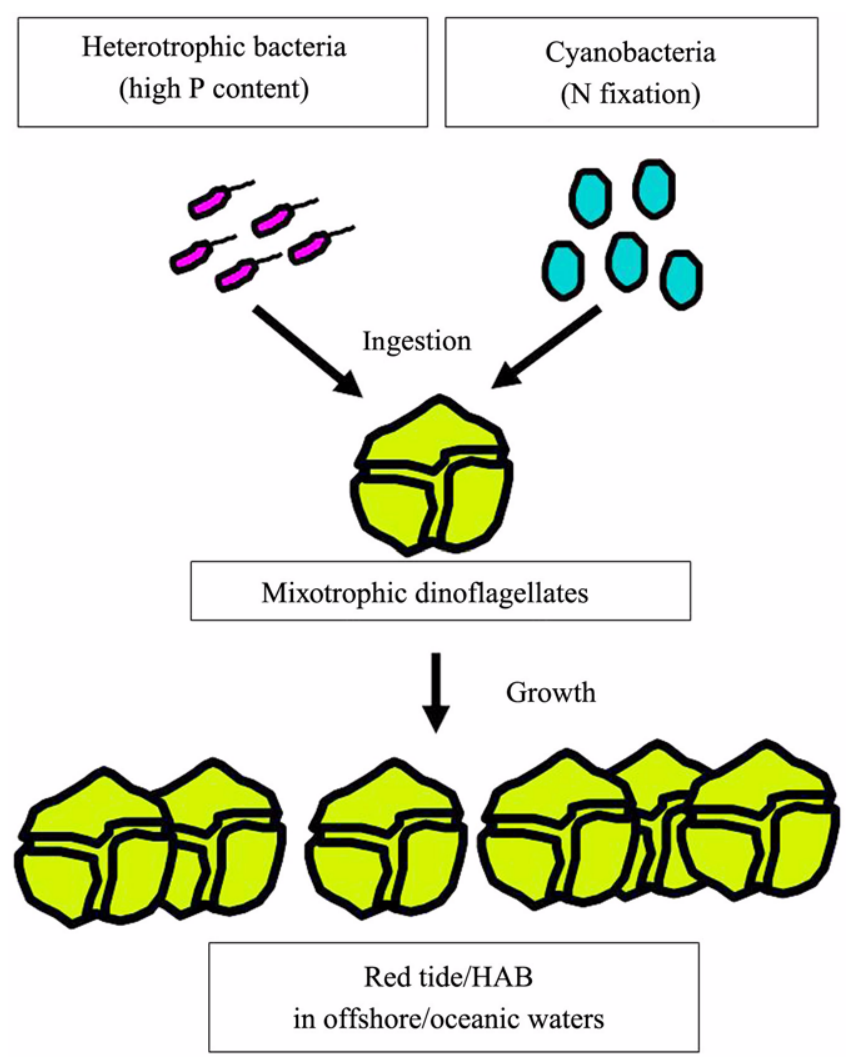

Fig. 9. A diagram on a possible mechanism of the outbreak and/ or persistence of red tides dominated by mixotrophic dinoflagellates in offshore and/or oceanic waters where inorganic nutrient concentrations are low. Mixotrophic dinoflagellates grow and form a red tide patch by feeding on some cyanobacteria which can conduct nitrogen fixation and on heterotrophic bacteria which usually have high phosphorus contents

donghaiense, and P. minimum in offshore and/or oceanic waters where the nutrient concentrations are low have been a mystery to the scientists. (2) Also, a red tide dominated by one MTD species has often been followed by a successive red tide dominated by another MTD species in a short period (a few days). When considering the photogrowth rate of the MTD species, the rapid succession of another MTD species in serial red tides has been difficult to explain. However, the discovery of mixotrophy in phototrophic dinoflagellates may give some clue on these unsolved issues.

By combining the results of Jeong et al. (2005b) and Seong et al. (2006), I propose a possible mechanism of the outbreak and/or the persistence of offshore or oceanic red tides (Fig. 9); many MTDs such as K. brevis, P. donghaiense, and P. minimum are able to feed on Synechococcus sp. and heterotrophic bacteria. Therefore, if the MTDs feed on some cyanobacteria which can conduct nitrogen fixation (e.g. Mitsui et al. 1986) and heterotrophic bacteria which usually have high $\mathrm{P}: \mathrm{N}$ ratios (e.g. Tezuka 1990), the MTDs are able to obtain nitrogen and phosphorus simultaneously for their growth in offshore or oceanic waters. It is worthwhile to test this hypothesis in offshore and oceanic waters.

Jeong et al. (2005c) suggested that feeding by larger MTDs on smaller MTDs may be a driving force for the succession of dominant species during serial red tides based on the their field data; in Masan Bay, Korea in 2004, a bloom dominated by a mixture of Amphidinium sp. and the raphidophyte Heterosigma akashiwo was followed by one dominated by a mixture of Prorocentrum minimum and $P$. triestinum, then by Cochclodinium polykrikoides, and then by $P$. micans in series. P. minimum and P. triestinum which were able to feed on $A$. carterae and $H$. akashiwo were ingested in turn by C. polykrikoides and P. micans (Jeong et al. 2004c, 2005c). Under these situations, nutrients may not play such an important role in the succession of dominant species during serial red tides; direct transfer of the materials and energy of the organisms that form a red tide into MTDs by predation may not need the uptake and release of nitrogen and phosphorus by the organisms. This may cause uncoupling between nutrient concentrations and MTD abundance in natural environments.

The discovery of mixotrophy in many phototrophic dinoflagellates may change our views of the mechanisms of the outbreak, persistence, and decline of red tides dominated by dinoflagellates, and also of the driving forces for succession in serial red tides. Therefore, to understand the process of red tides, we should consider mixotrophy in dominant dinoflagellates.

\section{Marine Planktonic Food Webs and Roles of Dinoflagellates}

Establishing the food webs in the marine planktonic community is one of the most important steps in understanding the cycling of materials and flows of energy and predicting further responses of marine ecosystems to diverse-scaleenvironmental changes. For the last four decades, several new ecological concepts in marine planktonic food webs have been established (Azam et al. 1983). In particular, dinoflagellates have been one of the triggers for discovering new pathways and in turn establishing new ecological concepts in marine ecosystems (Bockstahler and Coats 1993a; Jeong 1994b; Jeong et al. 2005b, 2008; Seong et al. 2006). 


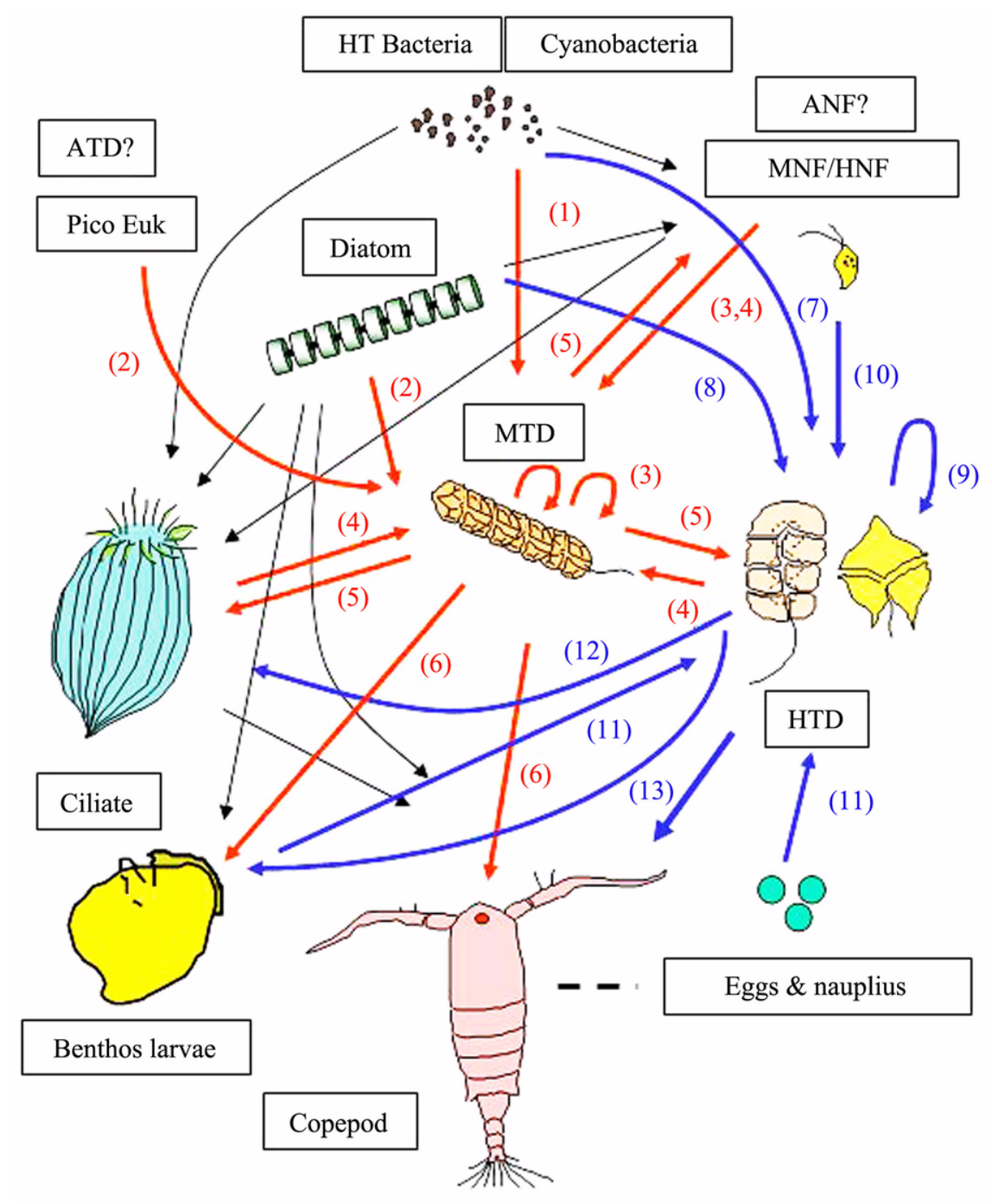

Fig. 10. A diagram of marine planktonic food webs focusing on dinoflagellates. Line (1): Feeding by mixotrophic dinoflagellates on bacteria (e.g. Jeong et al. 2005b; Seong et al. 2006). Line (2): Feeding by mixotrophic dinoflagellates on phytoplankton (e.g. Stoecker et al. 1997). Line (3): Feeding by mixotrophic dinoflagellates on other mixotrophic dinoflagellates and mixotrophic nanoflagellates (e.g. Jeong et al. 2005c). Line (4): Feeding by mixotrophic dinoflagellates on heterotrophic protists (e.g. Bockstahler and Coats 1993a). Line (5): Feeding by heterotrophic protists on mixotrophic dinoflagellates (e.g. Jeong and Latz 1994). Line (6): Feeding by metazooplankton on mixotrophic dinoflagellates (e.g. Turner and Tester 1997). Line (7): Feeding by heterotrophic dinoflagellates on bacteria (e.g. Jeong et al. 2008). Line (8): Feeding by heterotrophic dinoflagellates on phytoplankton (Hansen 1992; Jeong et al. 2004d). Line (9): Predator-prey relationships among heterotrophic dinoflagellates (Jeong et al. unpubl. data). Line (10): Feeding by heterotrophic dinoflagellates on heterotrophic protists (Jeong et al. 2007b). Line (11): Feeding by heterotrophic dinoflagellates on metazooplankton including eggs and naupliar stages (Jeong 1994b). Line (12): Feeding by heterotrophic protists on heterotrophic dinoflagellates (Jeong et al. 2004b). Line (13): Feeding by metazooplankton on heterotrophic dinoflagellates (Gifford and Dagg 1991). Are there any exclusively autotrophic nanoflagellate (ANF) or dinoflagellate (ATD)?

(HT bacteria: Heterotrophic bacteria, MTD: Mixotrophic dinoflagellates, HTD: Heterotrophic dinoflagellates, MNF: Mixotrophic nanoflagellate, HNF: Heterotrophic nanoflagellate, PicoEuk: Picoeukaryote)

For the last decade, several models, including mixotrophic protists in marine microbial food webs, have been established (Stoecker 1998; Stickney et al. 2000; Jost et al. 2004; Hammer and Pitchford 2005). However, these models may need to be modified in response to recent discoveries related to dinoflagellates. For example, the model established by Stickney et al. (2000) needs to include the data on the feeding by large MTDs on bacteria (Nygaard and Tobiesen 1993; Jeong et al. 2005b; Seong et al. 2006). Also, most models mentioned above have not included diverse predator- 


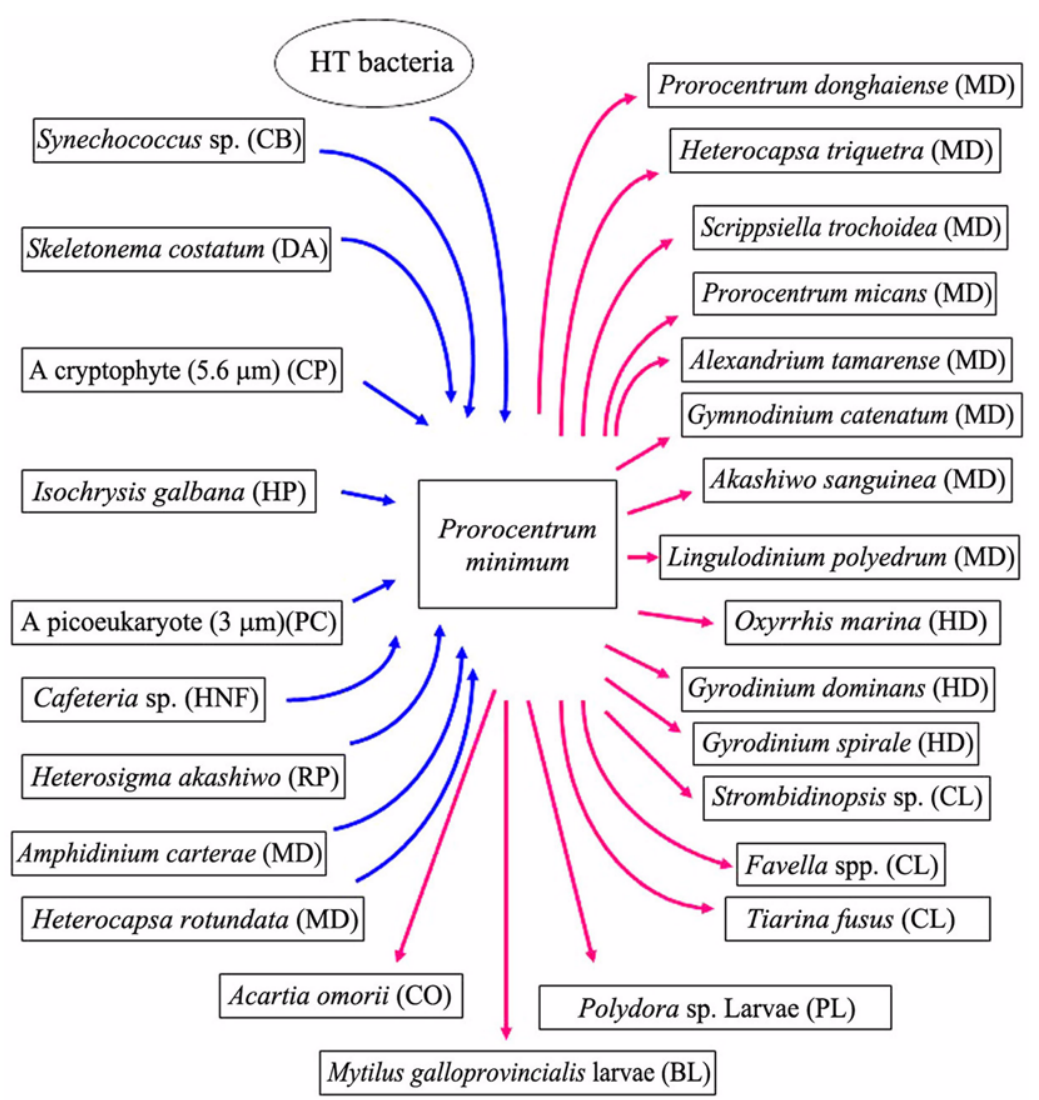

(A)

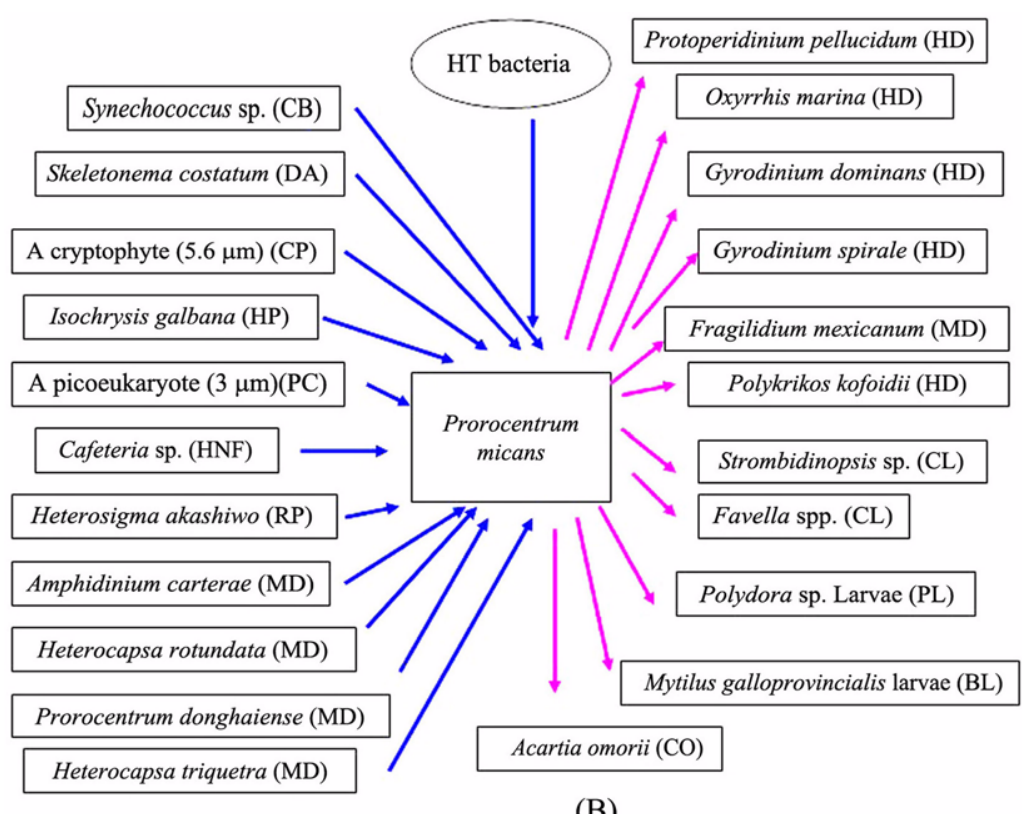

(B)

Fig. 11. The prey and predators of Prorocentrum minimum (A) and P. micans (B) so far reported. The blue-colored arrows (routes) emerging from the variety of prey all point to $P$. minimum or $P$. micans, while the red-colored arrows (routes) emerging from $P$. minimum or P. micans lead to the diverse predator species. P. minimum or P. micans box looks like a hub airport and thus we suggest calling each diagram "the Prorocentrum minimum hub" or "the Prorocentrum micans hub"

(BL: Bivalve larvae, CB: Cyanobacteria, CL: Ciliates, CO: Copepods, CP: Cryptophytes, DA: Diatoms, HD: Heterotrophic dinoflagellates, HNF: Heterotrophic nanoflagellates, HP: Haptophytes, HT bacteria: Heterotrophic bacteria, MD: Mixotrophic dinoflagellates, RP: Raphidophytes, PL: Polychaeta larvae, PC: Picoeukaryotes) 
prey relationships among MTDs at the species level and allocated only one or few boxes for mixotrophic organisms. The box should be split into many boxes because many MTDs coexist in water parcels, there are many predatorprey relationships among these MTDs, and the ecological niche of a mixotrophic dinoflagellate is different from that of other MTDs (Jeong et al. 2005c). Also, Hammer and Pitchford (2005) established a model to address the effect of mixotrophy in plankton bloom dynamics, mainly focussing on Model III mixotrophic organisms which are called photosynthetic "protozoa" by Stoecker (1998). They assummed that the portion of mixotrophs involving phytoplankton or zooplankton would be small. However, now many have been revealed to be MTDs and also all phototrophic dinoflagellates are suggested to be MTDs. Including large portions of MTDs into Model III mixotrophs may affect their results; mixotrophy may be a large perturbation to the predator-prey system in their model, not a small perturbation.

Based on literature and our recent findings, we established a diagram describing marine planktonic food webs focusing on dinoflagellates (Fig. 10). One of the most interesting things is the fact that the ecological roles of MTDs in marine plankton food webs are quite different from those of other phytoplankton such as diatoms and phototrophic nano- and microflagellates. Also, two diagrams could be drawn to describe predator-prey relationships between each of two different MTD species (e.g. Prorocentrum minimum and P. micans) and other plankton (Fig. 11). These two diagrams (so called, Prorocentrum minimum hub and $P$. micans hub) show that the prey and/or predators of one MTD species are quite different from those of the other MTD species. Therefore, each MTD may have a different ecological niche from that of other MTD species. These different ecological niches and thus they may give an explanation for the phytoplankton co-existence by Hutchinson (1961) and help us to understand the roles of each MTD in marine ecosystems at the species level and also to establish effective ecological models.

As described above, MTDs and HTDs interact with very diverse marine organisms and thus they play diverse roles in marine plankton food webs as follows; (1) in the community level, MTDs and HTDs are effective predators on diverse prey (taxa, size etc.) from bacteria (maybe virus) to metazoans due to their diverse feeding mechanisms. Also, in the species level, a dinoflagellate species is an effective predator on diverse prey items with a wide size range because it has 2 or more different feeding mechanisms depending on the type and/or size of prey. (2) Dinoflagellates are excellent prey for diverse heterotrophic protistan and metazoan predators. Thus, they sometimes play a role of a link between bacteria and some metazoan predators which are unable to ingest bacteria directly. (3) They are strong competitors with red-tide algae, HNFs, and ciliates for picoplankton and with ciliates and metazoans for nanoplankton and larger prey. (4) They sometimes control the populations of diverse prey and play the role of a driving force for rapid succession of dominant species in serial red tides. Also, grazing impact of dinoflagellates on a prey population is often higher or comparable to that of ciliates or copepods due to higher abundance. (5) Some dinoflagellates are able to detoxify phytotoxin. They may play a role of sinking phytotoxins from marine food webs. (6) Dinoflagellates make food webs long and complicated, but they make limited materials to be utilized in maximum. In particular, many predator-prey relationships among dinoflagellates make food webs more complex but support co-existence of many dinoflagellate species with separation of ecological niches at the level of species.

\section{Further Studies}

To understand the roles of MTDs and HTDs in marine plankton food webs, it is worth exploring the following questions in future researches: (1) Are there exclusively autotrophic dinoflagellates? So far, approximately 70 phototrophic dinoflagellates have been revealed to be mixotrophic (e.g. Jacobson and Anderson 1996; Stoecker 1999; Jeong et al. 2005c, 2010; Seong et al. 2006). Considering the fact that all the MTDs tested in our recent studies were able to feed on bacteria, and also that the endosymbiosis theory describing the origin of plastids is a widely accepted theory (Bhattacharya and Medlin 1995; Hackett et al. 2004; McFadden 2001; Yoon et al. 2002), other untested dinoflagellates may also be mixotrophic or heterotrophic. It is worthwhile testing the ability of phagotrophy in all phototrophic dinoflagellates not yet tested; (2) Plastids of phototrophic prey organisms belonging to diverse classes such as cyanophyta, cryptophyta, haptophyta, bacillariophyta, dinophyta, can be transferred into MTDs by predation (e.g. Jeong et al. 2005c). Thus, there is a chance that MTDs can contain diverse plastids originating from diverse classes. Feeding by MTDs on diverse 
phototrophic organisms having different plastids supports the hypothesis of tertiary endosymbiosis (ancestor of dinoflagellates engulfing a eukaryotic cell with a secondary plastid) and multiple origins of dinoflagellates (Bhattacharya et al. 2003). However, considering the ability of all MTDs tested in our study to feed on cyanobacterium Synechococcus (Jeong et al. 2005b), there may be some dinoflagellates containing plastids originating from cyanophyta. To explore evolution in algae, it is worthwhile exploring the relationships between the feeding occurrences, types of plastids, DNA sequences, and gene expression of MTDs and their prey. (3) There may be some predator-prey relationships between MTDs and other marine organisms so far not observed. For example, MTDs may feed on small heterotrophic nanoflagellates, or vice versa. However, this has been not tested yet. The discovery of unknown food webs is critical and serves our understanding of ecology and evolution in phototrophic organisms and increases the validity of ecological models and predictions. (4) DNA difference in dinoflagellates may cause difference in morphology and enzymes involving in feeding and digesting prey. Therefore, it is worthwhile exploring the relationships among phylogeny tree based on DNA sequence, morphology, feeding enzymes, and morphology of dinoflagellates.

\section{Acknowledgements}

We thank Jae Yeon Park, Seong Taek Kim, Jae Yoon Song, Jong Hyeok Kim, Soo Kyeom Kim for technical support. This paper was funded by grants from National Research Foundation (2009-0058298) and Ecological Disturbance Research Program, Korea Institute of Marine Science \& Technology Promotion/Ministry of Land, Transportation and Marine Affairs (KMLTM) award to HJ Jeong.

\section{References}

Adolf JE, Stoecker DK, Harding LW Jr (2006) The balance of autotrophy and heterotrophy during mixotrophic growth of Karlodinium micrum (Dinophyceae). J Plankton Res 28: 737751

Adolf JE, Krupatkina D, Bachvaroff T, Place AR (2007) Karlotoxin mediates grazing by Oxyrrhis marina on strains of Karlodinium veneficum. Harmful Algae 6:400-412

Azam F, Fenchel T, Field JG, Gray JS, Meyer-Reil L, Thingstad F (1983) The ecological role of water-column microbes in the sea. Mar Ecol Prog Ser 10:257-263
Azanza RV, Fukuyo Y, Yap LG, Takayama H (2005) Prorocentrum minimum bloom and its possible link to a massive fish kill in Bolinao, Pangasinan, Northern Philippines. Harmful Algae 4:519-524

Baek SH, Shimode J, Kikuchi T (2008) Growth of dinoflagellates, Ceratium furca and Ceratium fusus in Sagami Bay, Japan: the role of temperature, light intensity and photoperiod. Harmful algae 7:163-173

Berge T, Hansen PJ, Moestrup Ø (2008) Feeding mechanism, prey specificity and growth in light and dark of the plastidic dinoflagellate Karlodinium armiger. Aquat Microb Ecol 50: 279-288

Berggreen B, Hansen B, Kiørboe T (1988) Food size spectra, ingestion and growth of the copepod Acartia tonsa during development: implications for determination of copepod production. Mar Biol 99:341-352

Besiktepe S, Dam HG (2002) Coupling of ingestion and defecation as a function of diet in the calanoid copepod Acartia tonsa. Mar Ecol Prog Ser 229:151-164

Bhattacharya D, Medlin L (1995) The phylogeny of plastids: a review based on comparisons of small-subunit ribosomal RNA coding regions. J Phycol 31:489-498

Bhattacharya D, Yoon HS, Hackett JD (2003) Photosynthetic eukaryotic unite: endosymbiosis connects the dots. BioEssays 26:50-60

Biecheler B (1952) Recherches sur les Peridiniens. Bull Biol Fr Belg Suppl 36:1-149

Bockstahler KR, Coats DW (1993a) Grazing of the mixotrophic dinoflagellate Gymnodinium sanguineum on ciliate population of Chesapeake Bay. Mar Biol 116:447-487

Bockstahler KR, Coats DW (1993b) Spatial and temporal aspects of mixotrophy in Chesapeake Bay dinoflagellates. J Eukaryot Microbiol 40:49-60

Boenigk J, Arndt H (2000) Comparative studies on the feeding behavior of two heterotrophic nanoflagellates: the filterfeeding choanoflagellate Monosiga ovata and the raptorialfeeding kinetoplastid Rhynchomonas nasuta. Aquat Microb Ecol 22:243-249

Broglio E, Jonasdottir SH, Calbet A, Jakobsen HH, Saiz E (2003) Effect of heterotrophic versus autotrophic food on feeding and reproduction of the calanoid copepod Acartia tonsa: relationship with prey fatty acid composition. Aquat Microb Ecol 31:267-278

Burkholder JAM, Glasgow HB Jr (1995) Interactions of a toxic estuarine dinoflagellate with microbial predators and prey. Arch Protistenkd 145:177-188

Burkholder JAM, Glasgow HB Jr (1997) Trophic controls on stage transformations of a toxic ambush-predator dinoflagellate. J Eukaryot Microbiol 44:200-205

Burkholder JAM, Glibert PM, Skelton HM (2008) Mixotrophy, a major mode of nutrition for harmful algal species in eutrophic 
waters. Hamful Algae 8:77-93

Burkholder JAM, Noga EJ, Hobbs CW, Glasgow HB Jr, Smith SA (1992) New "phantom" dinoflagellate is the causative agent of major estuarine fish kills. Nature 358:407-410

Bursa AS (1961) The annual oceanographic cycle at Igloolik in the Canadian Arctic II. The Phytoplakton. J Fish Res Bd Can 18:563-615

Buskey EJ (1997) Behavioral components of feeding selectivity of the heterotrophic dinoflagellate Protoperidinium pellucidum. Mar Ecol Prog Ser 153:77-89

Buskey EJ, Coulter CJ, Brown SL (1994) Feeding, growth and bioluminescence of the heterotrophic dinoflagellate Protoperidinium huberi. Mar Biol 121:373-380

Calbet A, Vaque D, Felipe J, Vila M, Sala MM, Alcaraz M, Estrda M (2003) Relative grazing impact of microzooplankton and mesozooplankton on a bloom of the toxic dinoflagellate Alexandrium minutum. Mar Ecol Prog Ser 259:303-309

Cohen JH, Tester PA, Forward RB Jr (2007) Sublethal effects of the toxic dinoflagellate Karenia brevis on marine copepod behavior. J Plankton Res 29:301-315

Colin SP, Dam HG (2003) Effects of the toxic dinoflagellate Alexandrium fundyense on the copepod Acartia hudsonica: a test of the mechanisms that reduce ingestion rates. Mar Ecol Prog Ser 248:55-65

Daugbjerg N, Hansen G, Larsen J, Moestrup Ø (2000) Phylogeny of some major genera of dinoflagellates based on ultrastructure and partial LSU rDNA sequence data, including the erection of 3 new genera of unarmoured dinoflagellates. Phycologia 39:302-317

ECOHAB (1995) The ecology and oceanography of harmful algal blooms: a national research agenda. Woods Hole Oceanographic Institute, Woods Hole, MA, $66 \mathrm{p}$

Feinstein TN, Traslavina R, Sun M, Lin S (2002) Effects of light on photosynthesis, grazing, and population dynamics of the heterotrophic dinoflagellate Pfiesteria piscicida (Dinophyceae). J Phycol 38:659-669

Fenchel T (1987) Ecology of protozoa: the biology of free living phagotrophic protists. Springer-Verlag, New York, 197 p

Gaines G, Taylor FJR (1984) Extracellular digestion in marine dinoflagellates. J Plankton Res 6:1057-1061

Garces E, Fernandez M, Penna A, Van Lenning K, Gutierrez A, Camp J, Zapata M (2006) Characterization of MW Mediterranean Karlodinium spp. (Dinophyceae) strains using morphological, molecular, chemical, and physiological methodologies. J Phycol 42: 1096-1112

Gifford DJ, Dagg MJ (1991) The microzooplankton-mesozooplankton link: consumption of planktonic protozoa by the calanoid copepods Acartia tonsa Dana and Neocalanus plumchrus Murukawa. Mar Microb Food Webs 5:161-177

Glasgow HB, Lewitus AJ, Burkholder JAM (1998) Feeding behavior of the ichthyotoxic estuarine dinoflagellate, Pfiesteria piscicida, on amino acids, algal prey, and fish vs. Mammalian erythrocytes. In: Reguera B, Blanco J, Fernandez ML, Wyatt $\mathrm{T}$ (eds) Harmful microalgae. Intergovernmental Oceanographic Commission of UNESCO, Paris, pp 394-397

Goldman JC, Dennett MR, Gordin H (1989) Dynamics of herbivorous grazing by the heterotrophic dinoflagellate Oxyrrhis marina. J Plankton Res 11:391-407

Granéli E, Anderson DM, Carlsson P, Maestrini SY (1997) Light and dark carbon uptake by Dinophysis species in comparison to other photosynthetic and heterotrophic dinoflagellates. Aquat Microb Ecol 13:177-186

Hackett JD, Anderson DM, Erdner DL, Bhattacharya D (2004) Dinoflagellates: a remarkable evolutionary experiment. Am J Bot 91:1523-1534

Hammer A, Pitchford J (2005) The role of mixotrophy in plankton bloom dynamics, and the consequences for system productivity. J Mar Sci 62:833-840

Hansen FC, Witte HJ, Passarge J (1996) Grazing in the heterotrophic dinoflagellate Oxyrrhis marina: size selectivity and preference for calcified Emiliania hyxleyi cells. Aquat Microb Ecol 10:307-313

Hansen PJ (1989) The red tide dinoflagellate Alexandrium tamarense: effects on behaviour and growth of a tintinnid ciliate. Mar Ecol Prog Ser 53:105-116

Hansen PJ (1991) Quantitative importance and trophic role of heterotrophic dinoflagellates in a coastal pelagial food web. Mar Ecol Prog Ser 73:253-261

Hansen PJ (1992) Prey size selection, feeding rates and growth dynamics of heterotrophic dinoflagellates with special emphasis on Gyrodinium spirale. Mar Biol 114:327-334

Hansen PJ (1995) Growth and grazing response of a ciliate feeding on the red tide dinoflagellate Gyrodinium aureolum in monoculture and in mixture with a non-toxic alga. Mar Ecol Prog Ser 121:65-72

Hansen PJ (2002) Effect of high pH on the growth and survival of marine phytoplankton: implications for species succession. Aquat Microb Ecol 28:279-288

Hansen PJ, Lundholm N, Rost B (2007) Growth limitation in marine red-tide dinoflagellates: effects of $\mathrm{pH}$ versus inorganic carbon availability. Mar Ecol Prog Ser 334:63-71

Hansen PJ, Nielsen TG (1997) Mixotrophic feeding of Fragilidium subglobosum (Dinophyceae) on three species of Ceratium: effects of prey concentration, prey species and light intensity. Mar Ecol Prog Ser 147:187-196

Hansen PJ, Calado AJ (1999) Phagotrophic mechanisms and prey selection in free-living dinoflagellates. J Eukaryot Microbiol 46:382-389

Heinbokel JF, Coats DW, Henderson KW, Tyler MA (1988) Reproduction rates and secondary production of three species of the rotifer genus Synchaeta in the estuarine Potomac River. J Plankton Res 10:659-672 
Houde SEL, Roman M (1987) Effects of food quality on the functional ingestion response of the copepod Acatria tonsa. Mar Ecol Prog Ser 40:69-77

Huntley M, Barthel K-G, Star JL (1983) Particle rejection by Calanus pacificus: discrimination between similarly sized particles. Mar Biol 74:151-160

Huntley M, Sykes P, Rohan S, Marin V (1986) Chemicallymediated rejection of dinoflagellate prey by the copepods Calanus pacificus and Paracalanus parvus: mechanism, occurrence and significance. Mar Ecol Prog Ser 28:105-120

Huskin I, Anadon R, lvarez-Marqus F, Harris RP (2000) Ingestion, faecal pellet and egg production rates of Calanus helgolandicus feeding coccolithophorid versus non-coccolithophorid diets. J Exp Mar Biol Ecol 248:239-254

Hutchinson GE (1961) The paradox of the plankton. Am Nat 95: $137-145$

Jacobson DM (1987) The ecology and feeding biology of thecate heterotrophic dinoflagellates. Ph.D. Thesis, Woods Hole Oceanographic Institution/Massachusetts Institute of Technology Joint Program, 210 p

Jacobson DM, Anderson DM (1986) Thecate heterotrophic dinoflagellates: feeding behavior and mechanisms. J Phycol 22:249-258

Jacobson DM, Andersen RA (1994) The discovery of mixotrophy in photosynthetic species of Dinophysis (Dinophyceae): light and electron microscopical observations of food vacuoles in Dinophysis acuminata, D. norvegica and two heterotrophic dinophysoid dinoflagellates. Phycologia 33:97-110

Jacobson DM, Anderson DM (1996) Widespread phagocytosis of ciliates and other protists by marine mixotrophic and heterotrophic thecate dinoflagellates. J Phycol 32:279-285

Jakobsen HH, Hansen PJ (1997) Prey size selection, grazing and growth response of the small heterotrophic dinoflagellate Gymnodinium sp. and the ciliate Balanion comatum-a comparative study. Mar Ecol Prog Ser 158:75-86

Jakobsen HH, Hansen PJ, Larsen J (2000) Growth and grazing responses of two chloroplast-retaining dinoflagellates: Effect of irradiance and prey species. Mar Ecol Prog Ser 201: 121-128

Jeong HJ (1994a) Predation effects of the calanoid copepod Acartia tonsa on a population of the heterotrophic dinoflagellate Protoperidinium cf. divergens in the presence of co-occurring red-tide dinoflagellate prey. Mar Ecol Prog Ser 111:87-97

Jeong HJ (1994b) Predation by the heterotrophic dinoflagellate Protoperidinium cf. divergens on copepod eggs and early naupliar stages. Mar Ecol Prog Ser 114:203-208

Jeong HJ (1995) The interactions between microzooplanktonic grazers and dinoflagellates causing red tides in the open coastal waters off southern California. Ph.D. Thesis, Scripps Institution of Oceanography, University of California, San Diego, 139 p. Available on microfilm from University of Michigan,
Accession Number 223882

Jeong HJ (1999) The ecological roles of heterotrophic dinoflagellates in marine planktonic community. J Eukaryot Microbiol 46: 390-396

Jeong HJ, Latz MI (1994) Growth and grazing rates of the heterotrophic dinoflagellate Protoperidinium spp. on red tide dinoflagellates. Mar Ecol Prog Ser 106:173-185

Jeong HJ, Lee CW, Yih WH, Kim JS (1997) Fragilidium cf. mexicanum, a thecate mixotrophic dinoflagellate which is prey for and a predator on co-occuring thecate heterotrophic dinoflagellate Protoperidinium cf. divergens. Mar Ecol Prog Ser 151:299-305

Jeong HJ, Shim JH, Kim JS, Park JY, Lee CW, Lee Y (1999a) The feeding by the thecate mixotrophic dinoflagellate Fragilidium cf. mexicanum on red tide and toxic dinoflagellate. Mar Ecol Prog Ser 176:263-277

Jeong HJ, Shim JH, Lee CW, Kim JS, Koh SM (1999b) Growth and grazing rates of the marine planktonic ciliate Strombidinopsis sp. on red-tide and toxic dinoflagellates. J Eukaryot Microbiol 46:69-76

Jeong HJ, Kang HJ, Shim JH, Park JG, Kim JS, Song JY, Choi HJ (2001a) Interactions among the toxic dinoflagellate Amphidinium carterae, the heterotrophic dinoflagellate Oxyrrhis marina, and the calanoid copepods Acartia spp. Mar Ecol Prog Ser 218:77-86

Jeong HJ, Kim SK, Kim JS, Kim ST, Yoo YD, Yoon JY (2001b) Growth and grazing rates of the heterotrophic dinoflagellate Polykrikos kofoidii on red-tide and toxic dinoflagellates. J Eukaryot Microbiol 48:298-308

Jeong HJ, Yoon JY, Kim JS, Yoo YD, Seong KA (2002) Growth and grazing rates of the prostomatid ciliate Tiarina fusus on red-tide and toxic algae. Aquat Microb Ecol 28:289-297

Jeong HJ, Kim JS, Yoo YD, Kim ST, Kim TH, Park MG, Lee $\mathrm{CH}$, Seong KA, Kang NS, Shim JH (2003a) Feeding by the heterotrophic dinoflagellate Oxyrrhis marina on the red-tide raphidophyte Heterosigma akashiwo: a potential biological method to control red tides using mass-cultured grazers. J Eukaryot Microb 50:274-282

Jeong HJ, Park KH, Kim JS, Kang HJ, Kim CH, Choi HJ, Kim YS, Park JY, Park MG (2003b) Reduction in the toxicity caused by a toxic dinoflagellate Gymnodinium catenatum by the feeding of the heterotrophic dinoflagellate Polykrikos kofoidii. Aquat Microb Ecol 31:307-312

Jeong HJ, Song JY, Lee CH, Kim ST (2004a) Feeding by the larvae of the mussel Mytilus galloprovincialis on red-tide dinoflagellates. J Shellfish Res 23:185-195

Jeong HJ, Yoo YD, Kim JS, Kang NS, Kim TH, Kim JH (2004b) Feeding by the marine planktonic ciliate Strombidinopsis jeokjo on common heterotrophic dinoflagellates. Aquat Microb Ecol 36:181-187

Jeong HJ, Yoo YD, Kim JS, Kim TH, Kim JH, Kang NS, Yih 
WH (2004c) Mixotrophy in the phototrophic harmful alga Cochlodinium polykrikoides (Dinophycean): prey species, the effects of prey concentration and grazing impact. J Eukaryot Microbiol 51:563-569

Jeong HJ, Yoo YD, Kim ST, Kang NS (2004d) Feeding by the heterotrophic dinoflagellate Protoperidinium bipes on the diatom Skeletonema costatum. Aquat Microb Ecol 36:171-179

Jeong HJ, Kim JS, Kim JH, Kim ST, Seong KA, Kim TH, Song JY, Kim SK (2005a) Feeding and grazing impact by the newly described heterotrophic dinoflagellate Stoeckeria algicida on the harmful alga Heterosigma akashiwo. Mar Ecol Prog Ser 295:69-78

Jeong HJ, Park JY, Nho JH, Park MO, Ha JH, Seong KA, Jeng C, Seong CN, Lee KY, Yih WH (2005b) Feeding by red-tide dinoflagellates on the cyanobacterium Synechococcus. Aquat Microb Ecol 41:131-143

Jeong HJ, Yoo YD, Park JY, Song JY, Kim ST, Lee SH, Kim KY, Yih WH (2005c) Feeding by the phototrophic red-tide dinoflagellates: five species newly revealed and six species previously known to be mixotrophic. Aquat Microb Ecol 40:133-155

Jeong HJ, Yoo YD, Seong KA, Kim JH, Park JY, Kim SH, Lee SH, Ha JH, Yih WH (2005d) Feeding by the mixotrophic dinoflagellate Gonyaulax polygramma: mechanisms, prey species, the effects of prey concentration, and grazing impact. Aquat Microb Ecol 38:249-257

Jeong HJ, Ha JH, Park JY, Kim JH, Kang NS, Kim S, Kim JS, Yoo YD, Yih WH (2006) Distribution of the heterotrophic dinoflagellate Pfieteria piscicida in Korean waters and its feeding on mixotrophic dinoflagellates, raphidophytes, and fish blood cells. Aquat Microb Ecol 44:263-275

Jeong HJ, Ha JH, Yoo YD, Park JY, Kim JH, Kang NS, Kim TH, Kim HS, Yih WH (2007a) Feeding by the Pfiesteria-like heterotrophic dinoflagellate Luciella masanensis. J Eukaryot Microbiol 54:231-241

Jeong HJ, Song JE, Kang NS, Kim S, Yoo YD, Park JY (2007b) Feeding by heterotrophic dinoflagellates on the common marine heterotrophic nanoflagellate Cafeteria sp. Mar Ecol Prog Ser 333:151-160

Jeong HJ, Kim JS, Song JY, Kim JH, Kim TH, Kim SK, Kang NS (2007c) Feeding by heterotrophic protists and copepods on the heterotrophic dinoflagellates Pfiesteria pisicicida, Stoeckeria algicida, and Luciella masanensis. Mar Ecol Prog Ser 349:199-211

Jeong HJ, Seong KA, Yoo YD, Kim TH, Kang NS, Kim S, Park JY, Kim JS, Kim GH, Song JY (2008) Feeding and grazing impact by small marine heterotrophic dinoflagellates on hetertrophic bacteria. J Eukaryot Microbiol 55:271-288

Jeong HJ, Yoo YD, Kang NS, Rho JR, Seong KA, Park JW, Nam GS, Yih WH (2010) Ecology of Gymnodinium aureolum. I. Feeding in western Korean water. Aquat Microb Ecol 59:239-
255

Jost C, Lawrence CA, Campolongo F, van de Bund W, Hill S, DeAngelis DL (2004) The effects of mixotrophy on the stability and dynamics of a simple planktonic food web model. Theoret Popul Biol 66:37-51

Kamiyama T, Arima S (2001) Feeding characteristics of two tintinnid ciliate species on phytoplankton including harmful species: effects of prey size on ingestion rates and selectivity. J Exp Mar Biol Ecol 257:281-296

Kang NS, Jeong HJ, Moestrup Ø, Shin WG, Nam SW, Park JY, de Salas MF, Kim KW, Noh JH (2010) Description of a new planktonic mixotrophic dinoflagellate Paragymnodinium shiwhaense n. gen., n. sp. from the coastal waters off western Korea: morphology, pigments, and ribosomal DNA gene sequence. J Eukaryot Microbiol 57:121-144

Kim JS, Jeong HJ (2004) Feeding by the heterotrophic dinoflagellates Gyrodinium dominans and G. spirale on the red-tide dinoflagellate Prorocentrum minimum. Mar Ecol Prog Ser 280:85-94

Kondo K, Seike Y, Date Y (1990) Red tides in the brackish Lake Nakanoumi. (II). Relationships between the occurrence of Prorocentrum minimum red tide and environmental conditions. Bull Plankt Soc Japan Hiroshima 37:19-34

Koski M, Riser CW (2006) Post-bloom feeding of Calanus finmarchicus copepodites: selection for autotrophic versus heterotrophic prey. Mar Biol Res 2:109-119

Larsen J (1988) An ultrastructural study of Amphidinium poecilochroum (Dinophyceae), a phagotrophic dinoflagellate feeding on small species of cryptophytes. Phycologia 27:366377

Lee CW (1998) Growth and grazing rates of the heterotrophic dinoflagellate Oxyrrhis marina and the ciliate Stormbidinopsis sp. on Prorocentrum spp. M.A. Thesis, Kunsan National University, 36 p (In Korean with English abstract)

Lee SH (2006) Feeding by mixotrophic red-tide algae on photosynthetic picoeukaryotes. M.A. Thesis, Seoul National University, 55 p (In Korean with English abstract)

Legrand C, Graneli E, Carlsson P (1998) Induced phagotrophy in the photosynthetic dinoflagellate Heterocapsa triquetra. Aquat Microb Ecol 15:65-75

Lessard EJ (1984) Oceanic heterotrophic dinoflagellates: distribution, abundance and role as microzooplankton. Ph.D. Thesis, University of Rhode Island, Kingstown, $166 \mathrm{p}$

Lessard EJ, Swift E (1985) Species-specific grazing rates of heterotrophic dinoflagellates in oceanic waters, measured with a dual-label radioisotope technique. Mar Biol 87:289296

Li A, Stoecker DK, Coats DW, Adam EJ (1996) Ingestion of fluorescently-labeled and phycoerythrin-containing prey by photosynthetic dinoflagellates. Aquat Microb Ecol 10:139-147

Li A, Stoecker DK, Coats DW (2000) Mixotrophy in Gyrodinium 
galatheanum (dinophyceae): grazing responses to light intensity and inorganic nutrients. J Phycol 36:33-45

Liu S, Wang W-X (2002) Feeding and reproductive responses of marine copepods in South China Sea to toxic and nontoxic phytoplankton. Mar Biol 140:595-603

Maneiro I, Frangopulos M, Guisande C, Fernandez M, Reguera B, Riveiro I (2000) Zooplankton as a potential vector of diarrhetic shellfish poisoning toxins through the food web. Mar Ecol Prog Ser 201:155-163

Mason PL, Litaker RW, Jeong HJ, Ha JH, Reece KS, Vogelbein WK, Stokes NA, Park JY, Steidinger KA, Vandersea MW, Kibler S, Tester PA, Vogelbein WK (2007) Description of a new genus of Pfiesteria-like dinoflagellate, Luciella gen. nov. (dinophyceae), including two new species: Luciella masanensis sp. nov. and Luciella atlantis sp. nov. J Phycol 43:799-810

Matsubara T, Nagasoe S, Amasaki Y, Shikata T, Shimasaki Y, Oshima Y, Honjo T (2007) Effects of temperature, salinity, and irradiance on the growth of the dinoflagellate Akashiwo sanguinea. J Exp Mar Biol Ecol 342:226-230

McFadden GI (2001) Primary and secondary endosymbiosis and the origin of plastids. J Phycol 37:951-959

Menden-Deuer S, Lessard EJ, Sattergerg J, Grnbaum D (2005) Growth rates and starvation survival of three species of the pallium-feeding, thecate dinoflagellate genus Protoperidinium. Aquat Microb Ecol 41:145-152

Mitsui A, Cao S, Takahashi A, Arai T (1986) Growth synchrony and cellular parameters of the unicellular nitrogen-fixing marine cyanobacterium, Synechococcus $\mathrm{sp}$. strain Miami BG 043511 under continuous illumination. Physiol Plant 69:1-8

Nagasoe S, Kim DI, Shimasaki Y, Oshima Y, Yamaguchi M, Honjo T (2006) Effects of temperature, salinity and irradiance on the growth of the red tide dinoflagellate Gyrodinium instriatum Freudenthal et Lee. Harmful algae 5:20-25

Nakamura Y, Suzuki S, Hiromi J (1995) Population dynamics of heterotiophic dinoflagellates during a Gymnodinium mikimotoi red tide in the Seto Inland Sea. Mar Ecol Prog Ser 125:269-277

Nakamura Y, Yamazaki Y, Hiromi J (1992) Growth and grazing of a heterotrophic dinoflagellate, Gyrodinium dominans, feeding on a red tide flagellate, Chattonella antiqua. Mar Ecol Prog Ser 82:275-279

Naustvoll L-J (1998) Growth and grazing by the thecate heterotrophic dinoflagellate Diplopsalis lenticula (Diplopsalidaceae, Dinophyceae). Phycologia 37:1-9

Naustvoll L-J (2000) Prey size spectra and food preferences in thecate heterotrophic dinoflagellates. Phycologia 39:187-198

Navarro JM, Muoz MG, Contreras AM (2006) Temperature as a factor regulating growth and toxin content in the dinoflagellate Alexandrium catenella. Harmful algae 5:762-769

Nygaard K, Tobiesen A (1993) Bacterivory in algae: a survival strategy during nutrient limitation. Limnol Oceanogr 38:273-
279

Park MG, Kim SJ, Kim HS, Myung GO, Kang IG, Yih WH (2006) First successful culture of the marine dinoflagellate Dinophysis acuminata. Aquat Microb Ecol 45:101-106

Parrow MW, Glasgow HB, Burkholder JM, Zhang C (2001) Comparative response to algal prey by Pfiesteria piscicida, Pfiesteria shumwayae and an estuarine 'lookalike' species. In: Hallegraeff GM, Blackburn S, Bolch C, Lewis R (eds) Intergovernmental Oceanographic Commission of UNESCO, Paris, pp 101-104

Radi T, Pospelova V, de Vernal A, Vaughn Barrie J (2007) Dinoflagellate cysts as indicators of water quality and productivity in British Columbia estuarine environments. Mar Micropaleontol 62:269-297

Richardson TL, Pinckney JL, Walker EA, Marshalonis DM (2006) Photopigment radiolabelling as a tool for determining in situ growth rates of the toxic dinoflagellate Karenia brevis (Dinophyceae) Eur J Phycol 41:415-423

Roman M, Reaugh M, Zhang X (2006) Ingestion of the dinoflagellate, Pfiesteria piscicida, by the calanoid copepod, Acartia tonsa. Harmful algae 5:435-441

Rublee PA, Allen C, Schaefer Rhodes EL, Adamson J, Lapworth C, Burkholder J, Glasgow H (2004) Global distribution of toxic Pfiesteria complex species detected by PCR asssay. In: Steidinger KA, Landsberg JH, Tomas CR, Vargo G (eds) Harmful algae 2002. Intergovernmental Oceanographic Commission of UNESCO, Paris, pp 320-322

Scura ED, Jerde C (1977) Various species of phytoplankton as food for larval northern anchovy, Engraulis mordax, and relative nutritional values of the dinoflagellate Gymnodinuim splendens and Gonyaulax polyedra. Fish Bull 75:577-583

Seong KA, Jeong HJ, Kim S, Kim GH, Kang JH (2006) Bacterivory by co-occurring red-tide algae, heterotrophic nanoflagellates, and ciliates on marine bacteria. Mar Ecol Prog Ser 322:85-97

Sherr EB, Sherr BF (2002) Significance of predation by protists in aquatic microbial food webs. Ant van Leeuwenh 81:293308

Siano R, Montresor M (2005) Morphology, ultrastructure and feeding behaviour of Protoperidinium vorax sp. nov. (Dinophyceae, Peridiniales). Eur J Phycol 40:221-232

Skovgaard A (1996a) Engulfment of Ceratium spp. (Dinophyceae) by the thecate photosynthetic dinoflagellate Fragilidium subglobosum. Phycologia 35:490-499

Skovgaard A (1996b) Mixotrophy in Fragilidium subglobosum (Dinophyceae): growth and grazing responses as functions of light intensity. Mar Ecol Prog Ser 143:247-253

Skovgaard A (1998) Role of chloroplast retention in a marine dinoflagellate. Aquat Microb Ecol 15:293-301

Skovgaard A (2000) A phagotrophically derivable growth factor in the plastidic dinoflagellate Gyrodinium resplendens 
(Dinophyceae). J Phycol 36:1069-1078

Skovgaard A, Hansen PJ, Stoecker DK (2000) Physiology of the mixotrophic dinoflagellate Fragilidium subglobosum. 1. Effects of phagotrophy and irradiance on photosynthesis and carbon content. Mar Ecol Prog Ser 201:129-136

Sleigh MA (1989) Protozoa and other protists. Edward Arnold, London, $342 \mathrm{p}$

Smalley GW, Coats DW (2002) Ecology of the red-tide dinoflagellate Ceratium furca: distribution, mixotrophy, and grazing impact on ciliate populations of Chesapeake Bay. J Eukaryot Microbiol 49:63-73

Smalley GW, Coats DW, Adam EJ (1999) A new method using fluorescent microspheres to determine grazing on ciliates by the mixotrophic dinoflagellate Ceratium furca. Aquat Microb Ecol 17:167-179

Smalley GW, Coats DW, Stoecker DK (2003) Feeding in the mixotrophic dinoflagellate Ceratium furca is influenced by intracellular nutrient concentrations. Mar Ecol Prog Ser 262:137-151

Smayda TJ (1997) Harmful algal blooms: their ecophysiology and general relevance to phytoplankton blooms in the sea. Limnol Oceanogr 42:1137-1153

Steidinger KA, Burkholder JM, Glasgow HB Jr, Hobbs CW, Garrett JK, Truby EW, Noga EJ, Smith SA (1996) Pfiesteria piscicida gen. et sp. nov. (Pfiesteriaceae fam. nov.), a new toxic dinoflagellate with a complex life cycle and behavior. $\mathrm{J}$ Phycol 32:157-164

Stickney HL, Hood RR, Stoecker DK (2000) The impact of mixotrophy on planktonic trophic dynamics in marine ecosystems. Ecol Model 125:203-230

Stoecker DK (1998) Conceptual models of mixotrophy in planktonic protists and some ecological and evolutionary implications. Eur J Protistol 34:281-290

Stoecker DK (1999) Mixotrophy among dinoflagellates. J Eukaryot Microbiol 46:397-401

Stoecker DK, Evans GT (1985) Effects of protozoan herbivory and carnivory in a microplankton food web. Mar Ecol Prog 25:159-167

Stoecker DK, Guillard RRL, Kavee RM (1981) Selective predation by Favella ehrenbergii (Tintinnida) on and among dinoflagellates. Biol Bull 160:136-145

Stoecker DK, Li A, Coats DW, Gustafson DE, Nannen MK (1997) Mixotrophy in the dinoflagellate Prorocentrum minimum. Mar Ecol Prog Ser 152:1-12

Stoecker DK, Parrow MW, Burkholder JM, Glasgow HB Jr (2002) Grazing by microzooplankton on Pfiesteria piscicida cultures with different histories of toxicity Aquat Microb Ecol 28:79-85

Strom SL (1991) Growth and grazing rates of the herbivorous dinoflagellate Gymnodinium sp. from the open subarctic Pacific Ocean. Mar Ecol Prog Ser 78:103-113
Strom SL, Buskey EJ (1993) Feeding, growth, and behavior of the thecate heterotrophic dinoflagellate Oblea rotunda. Limnol Oceanogr 38:965-977

Tester PA, Turner JT, Shea D (2000) Vectorial transport of toxins from the dinoflagellate Gymnodinium breve through copepods to fish. J Plankton Res 22:47-62

Tezuka Y (1990) Bacterial regeneration of ammonium and phosphate as affected by the carbon: nitrogen: phosphorus ratio of organic substrates. Microb Ecol 19:227-238

Tillmann U (2004) Interactions between planktonic microalgae and protozoan grazers. J Eukaryot Microbiol 51:156-168

Tillmann U, John U (2002) Toxic effects of Alexandrium spp. on heterotrophic dinoflagellates: an allelochemical defence mechanism independent of PSP-toxin content. Mar Ecol Prog Ser 230:47-58

Turner JT, Anderson DM (1983) Zooplankton grazing during dinoflagellate blooms in a Cape Cod embayment, with observations of predation upon tintinnids by copepods. Mar Ecol 4:359-374

Turner JT, Tester PA (1997) Toxic marine phytoplankton, zooplankton grazers, and pelagic food webs. Limnol Oceanogr 42:1203-1214

Uchida T, Kamiyama T, Matsuyama Y (1997) Predation by a photosynthetic dinoflagellate Gyrodinium instriatum on loricated ciliates. J Plankton Res 19:603-608

Uye SI, Takamatsu K (1990) Feeding interactions between planktonic copepods and red-tide flagellates from Japanese coastal waters. Mar Ecol Prog Ser 59:97-107

Verity PG, Paffenhöfer G-A (1996) On assessment of prey ingestion by copepods. J Plankton Res 18:1767-1779

Watanabe MM, Suda S, Inouye I, Sawaguchi T, Chihara M (1990) Lepidodinium viride gen. et sp. nov. (Gymnodiniales, Dinophyta), a green dinoflagellate with a chlorophyll a- and b-containing endosymbiont. J Phycol 26:741-751

Watras CJ, Garcon VC, Olson RJ, Chisholm SW, Anderson DM (1985) The effect of zooplankton grazing on estuarine blooms of the toxic dinoflagellate Gonyaulax tamarensis. J Plankton Res 7:891-908

Yamaguch M, Shigeru I, Nagasaki K, Matsuyama Y, Uchida T, Imai I (1997) Effects of temperature and salinity on the growth of the red tide flagellates Heterocapsa circularisquama (Dinophyceae) and Chattonella verruculosa (Raphidophyceae). J Plankton Res 19:1167-1174

Yamamoto T, Tarutani K (1997) Effects of temperature, salinity and irradiance on the growth of toxic dinoflagellate Alexandrium tamarense isolated from Hiroshima bay, Japan. Japanese J Phycol 45:95-101 (In Japanese with English abstract)

Yoo YD, Jeong HJ, Kim MS, Kang NS, Song JY, Shin WG, Kim KY, Lee KT (2009) Feeding by phototrophic red-tide dinoflagellates on the ubiquitous marine diatom Skeletonema 
costatum. J Eukaryot Microbiol 56:413-420

Yoo YD, Jeong HJ, Kang NS, Song JY, Kim KY, Lee KT, Kim JH (2010) Feeding by the newly described mixotrophic dinoflagellate Paragymnodinium shiwhaense: feeding mechanism, prey species, and effect of prey concentration. J Eukaryot

\section{Microbiol 57:145-158}

Yoon HS, Hackett JD, Pinto G, Bhattacharya D (2002) The single, ancient origin of chromist plastids. Proc Natl Acad Sci USA 99:15507-15512 